Revista de Derecho

Universidad Católica del Norte

Sección: Ensayos

Ańo 17 - No 2, 2010

pp. 239-297

\title{
REVISIÓN DEL ÁMBITO DE APLICACIÓN SUBJETIVO Y OBJETIVO DE LA NOCIÓN DE USO DE INFORMACIÓN PRIVILEGIADA EN CHILE: UN EXAMEN DE LA NORMATIVA A LA LUZ DE LAS TENDENCIAS DOCTRINALES Y JURISPRUDENCIALES*
}

\section{María Fernanda VásQuez Palma**}

RESUMEN: Este trabajo analiza el ámbito de aplicación subjetivo y objetivo de la noción de "uso de información privilegiada" consagrada en la legislación chilena, detectando sus principales problemas de interpretación y aplicación. Para ello se tomará en consideración la realización de un examen hermenéutico de las normas en cuestión, las tendencias existentes en Derecho comparado, y últimos fallos dictados en Chile sobre esta materia.

PALABRAS CLAVE: Análisis - Noción - Uso - Información privilegiada.

\section{REVIEW OF THE SCOPE OF OBJECTIVE AND SUBJECTIVE APPLICATION OF THE NOTION OF THE USE OF PRIVILEGED INFORMATION IN CHILE: AN EXAMINATION OF THE NORM IN THE LIGHT OF DOCTRINAL AND JURISPRUDENCE TRENDS}

ABSTRACT: This piece of work analyzes the scope of the objective and subjective application of the notion of the "use of privileged information" established in the Chilean legislation, detecting its main problems of interpretation and application. To achieve that an hermeneutical examination of said norms will be considered, as well as

Este trabajo se ha elaborado en el marco del Proyecto de Investigación de la Dirección de Investigación de la Universidad de Talca (I001268), denominado "Aspectos jurídicos del concepto de uso de la información privilegiada en el mercado de valores chileno: revisión de sus implicancias y propuestas de una nueva construcción normativa", del que la autora es investigadora responsable. Tabla de abreviaturas: LMV: Ley de Mercado de Valores; OPA: Oferta Pública de acciones; OPAs: Oferta Pública de Adquisición de acciones. SVS: Superintendencia de Valores y Seguros.

Fecha de recepción: 27 de octubre de 2010.

Fecha de aceptación: 20 de diciembre de 2010.

** Profesora de Derecho Comercial, Universidad de Talca (CHile). Doctora en Derecho, Universidad Complutense de Madrid (España). Correo electrónico: mfvasquez@utalca.cl 
the existing trends in Comparative Law and the last rulings on the matter sentenced in Chile.

KEY WORDS: Analysis - Notion - Use of privileged information.

\section{EXPOSICIÓN GENERAL DEL PROBLEMA}

Si bien la ley sobre Mercado de Valores No 18.045 (LMV), que regula el uso de la información privilegiada, es relativamente reciente (1981), hasta la fecha ha sufrido variadas e importantes reformas por medio de las leyes No 19.301 (1994), 19.389 (1995), 19.705 (2000), 19.769 (2001), y la reciente ley $20.382(2009)^{1}$. De la evolución legislativa descrita se desprende que se trata de un concepto vivo que está en proceso de afinación y evolución. Concordante con esta afirmación, la mayor parte de la doctrina chilena ha planteado sistemáticamente variadas inquietudes y reparos sobre esta noción expuestas desde distintos focos de atención ${ }^{2}$. Asimismo, los escasos fallos dictados sobre el particular, han manifestado una ausencia de criterios de interpretación claros y unívocos sobre el particular. Estos y otros factores han evidenciado la necesidad de realizar un estudio exhaustivo sobre la materia.

En tal contexto, el presente estudio parte de la base que la regulación normativa existente en Chile sobre el concepto de "uso de la información privilegiada" no genera fácil consenso en su delimitación e interpretación, lo que trasunta del plano meramente teórico al práctico apreciable de manera concreta en los distintos casos que se han debido resolver. Derivado de ello, resulta crucial detectar posibles conflictos, brindar un diagnóstico y señalar las causas de las problemáticas planteadas, seguida de la propuesta de algunas soluciones en pos de la construc-

1 Que introduce perfeccionamiento a la normativa que regula los gobiernos corporativos de las empresas. A ello se debe agregar la existencia de un proyecto legislativo que en la actualidad se encuentra debatiéndose en el Congreso Nacional.

2 Entre los autores que se han abocado al estudio de esta temática en Chile se encuentran: GuZmÁn Anrique, Francisco (2009). Información privilegiada en el mercado de valores chileno, Santiago: Legal Publishing; Salah Abulseme, María Agnes (2005). Responsabilidad por uso de información privilegiada en el mercado de valores, Santiago: LexisNexis; Alcalde RoDRÍGUEZ, Enrique (2000). "Uso de información privilegiada: algunas consideraciones sobre el sentido y alcance de la prohibición en relación con su sujeto, objeto y sanción", Revista Chilena de Derecho No 27 1, pp. 11-28; Giesze, Craig R, (1999). "El análisis económico de la información privilegiada en el mercado de capitales y valores: ¿justicia ineficiente?”, Revista Chilena de Derecho No 26, pp. 799-838; Prado Puga, Arturo, (2003). "Acerca del concepto de información privilegiada en el mercado de valores chileno: su alcance, contenido y límites", Revista Chilena de Derecho, No 30.2, pp. 237-269; Ried Undurraga, José Miguel (2004). "Fundamentos de la prohibición del uso de la información privilegiada en Chile: una visión crítica", Revista Chilena del Derecho, No 31.3, pp. 439-463. 
ción de unas nomenclaturas más adecuadas a las finalidades pretendidas en esta institución.

Debido a la envergadura de esta temática, nos ocuparemos -por ahora- de un campo acotado de la misma, como es, el ámbito de aplicación objetivo y subjetivo de esta noción ${ }^{3}$, lo que trasuntará principalmente en el examen de los artículos 164 y 165 de la LMV, y en alguna medida el Art. 166 de la citada ley. Las preguntas que nos guían, son, entre otras: ¿Qué es la información privilegiada?; ¿cómo se construye tal definición (a partir de qué elementos)?; ¿quiénes son los posibles responsables de este uso y en razón de qué fundamentos?; y ¿cuál es la conducta ilícita que se sanciona? Frente a las primeras inquietudes debemos considerar que el legislador solo da cuenta de lo que comprende esta nomenclatura bajo una enumeración aparentemente taxativa, pero infinitamente amplia en su enunciado; igualmente se vislumbra que si bien la normativa señala "cualquier persona", evidentemente se precisa de un mayor trabajo de disección para determinar a los sujetos y fuentes obligacionales que subyacen a este planteamiento. Lo anterior puede extrapolarse respecto de la última interrogante, toda vez que la construcción y determinación de la "conducta castigada" utiliza como fuente basal el concepto de "uso de la información privilegiada", por lo que se encuentran directamente ligados.

Los objetivos de este artículo se centran, de manera general en: 1. Poner a disposición de la comunidad jurídica un completo análisis del régimen que actualmente impera respecto de la noción del uso de la información privilegiada en Chile; 2. Determinar los sujetos y conductas involucradas en este mandato legal; 3. Vislumbrar las problemáticas asociadas a los temas propuestos; y 4 . Proponer posibles mejoras a este régimen, con el objeto de que ellas sean consideradas por el intérprete $y$, en el futuro, por el legislador en pos de la optimización normativa de este instituto. En especial se intentará significar de contenido el instituto de información privilegiada y analizar en profundidad las aristas involucradas a partir del marco normativo existente ${ }^{4}$.

3 La investigación que se presenta corresponde a la primera parte de un trabajo de mayor extensión que presupuesta tres artículos. En los restantes nos hacemos cargo de: a. Los instrumentos jurídico-públicos que emerge de la potestad legislativa contra el empleo de la información privilegiada, en un análisis efectuado a la luz de la nueva regulación sobre gobiernos corporativos; y b. El estudio del régimen sancionador establecido a partir del uso de información privilegiada en Chile, indagando especialmente su coherencia y eficacia desde el conjunto normativo y principios afectados.

4 Para ello, se recurrirá tanto a fuentes normativas, en las cuales se incluirá parte de la historia de la ley y a fuentes bibliográficas. También se acudirá a la doctrina jurisprudencial que se ha asentado en estos últimos ańos, tanto en su calidad de fuente normativa, dada su incidencia en la construcción terminológica, como para el conocimiento de la aplicación del ordenamiento jurídico, manteniendo un alto nivel de rigurosidad en el análisis de las mismas. 
Como es imposible comprender la noción en comento sin referirnos a sus cimientos, en la primera parte revisaremos los presupuestos y objetivos de la institución que nos ocupa; y en forma sucinta, a los aspectos histórico-legislativos de la noción de uso de información privilegiada en Chile; en la segunda realizaremos un análisis del ámbito de aplicación objetiva; para en la siguiente hacer lo propio con el ámbito de aplicación subjetiva; dejamos reservado para la parte final, y a modo de conclusión, un estudio sobre las principales problemáticas que hemos vislumbrado con sus posibles soluciones.

La metodología empleada será la propia de la investigación jurídica. A partir del método sistemático, catalogaremos y ordenaremos el fenómeno en análisis. A través del exegético, analizaremos las disposiciones legales que rigen el uso de la información privilegiada en el mercado de valores chileno. Desde un enfoque comparado contrastaremos parte de nuestras afirmaciones y construiremos probables soluciones considerando para ello lo planteado por los regímenes jurídicos más avanzados en la materia. Concluiremos con el método hermenéutico y con la aplicación de la lógica jurídica para profundizar en cada uno de los problemas y soluciones propuestas.

\section{1) CONTEXTUALIZACIÓN PREVIA: IDENTIFICACIÓN Y ANÁLISIS DE LOS FUNDAMENTOS QUE DIERON ORIGEN AL SISTEMA NORMATIVO IM- PERANTE}

\section{1) BIEN JURÍdico PROTEGIDO: ¿̨POR QUÉ ESTÁ PROHIBIDO EL USO DE LA INFORMACIÓN PRIVILEGIADA?}

El uso de la información privilegiada se inserta dentro de un tema más amplio que se conoce como "abusos de mercado" 5 . En esencia, se trata de una conducta que, desde un punto de vista económico, hace peligrar o lesiona la función pública de la información en cuanto criterio de justa distribución del riesgo negocial en el mercado de valores ${ }^{6}$. Lo que se pretende por medio de su regulación, entonces, es preservar la confianza de los inversores y la integridad de los mercados, protegiendo al inversor frente a los riesgos que se derivan de la asimetría de la información, es decir, frente al peligro de que algunos inversores se vean perjudicados al no tener acceso a la información financiera o no ser capaces de utilizarla

5 Véase: García SAntos, Ma. Nieves, (2005). "Ética, equidad y normas de conducta en los mercados de valores: la regulación del abuso de mercado", Revista ética y Economía, No 823, pp. 163-183.

6 Véase: entre otros, Zunzunegui, F, (2005). Derecho del mercado financiero, $3^{\circ}$ edición, Madrid-Barcelona: Marcial Pons, pp. 26 -30. 
correctamente $^{7}$. Desde esta óptica, el bien jurídico protegido es el mecanismo de la libre formación de precios con el fin de garantizar la transparencia e igualdad de oportunidades entre los inversores ${ }^{8}$.

Derivado de lo anterior, la regulación de la información privilegia$\mathrm{da}^{9}$ nace para responder a la necesidad de mantener ciertos principios del buen funcionamiento del mercado de valores, como son la transparencia, la confidencialidad y la igualdad ${ }^{10}$, todos basados predominantemente en la información y su uso ${ }^{11}$, con el objeto de tutelar eficientemente al inversionista y la rentabilidad de su inversión. En tal contexto, la regulación del uso de información privilegiada surge como un instrumento preventivo $^{12}$, diseñado para evitar cualquier manipulación que pueda

7 Con todo, si seguimos la historia de esta regulación, vislumbraremos que no ha existido unicidad sobre la materia. Por ejemplo, en EEUU se fundó primero la prohibición en la igualdad de acceso de los agentes del mercado a la información (equal access theory), pasando por el fraude (securities fraud) y el deber fiduciario (fiduciary duty), actualmente tal fundamento recae en la tesis de la apropiación indebida (misappropiation theory). Véase: GuZMán Anrique (2009) 19-46; Salah Abusleme (2005) 88-116.

$8 \quad$ Siguiendo este planteamiento, en el caso de los delitos económicos, el objeto de protección es la confianza de los actores del sistema económico en el modo de funcionamiento de este. Véase: Piña Rochefort, Juan Ignacio (2010), en González Iturria, Marco (Editor): Regulaciones en el mercado de valores, Cuadernos de extensión jurídica No 19, Santiago: Universidad de los Andes, pp. 115 -120; Arroyo Zapatero, Luis (1994). El abuso de información privilegiada en el Derecho penal español, Estudios de Derecho penal económico, Cuenca (España): Ediciones de la Universidad Castilla-La Mancha, pp. 45-46.

9 Doctrinalmente se han dado variadas definiciones, por ejemplo: "Aquella información que presentando caracteres de relevancia y concreción, no ha sido divulgada al mercado, de manera que su conocimiento pertenece a un reducido número de individuos, que al acceder a ella, sea por sus funciones o relaciones dentro del mercado de valores, se sitúan en un nivel privilegiado al conocer hechos o antecedentes de importancia por su impacto en el evento que sean divulgadas"; desde una óptica más simplificada se ha dicho que es "toda información sobre la empresa o el mercado de sus títulos, de naturaleza tal que influya en el valor, que sea precisa por su contenido, cierta en cuanto a su realización y todavía desconocida para el público”. Gómez Iniesta, Carlos (1997). La utilización abusiva de información privilegiada en el mercado de valores, Madrid: McGraw-Hill, pp. 465-466.

10 Superintendencia de Valores y Seguros (1998). "Dictámenes del Mercado del Mercado de Valores, Informe Interno de la Fiscalía de Valores de 14 de octubre de 1997", Revista de Valores, No 121 , pp. 58 - 60.

11 Véase: Castells, Manuel (2008). La era de la información, Vol. I., Madrid: Alianza Editorial, pp. 111-185.

12 Sobre los mecanismos de eficiencia del mercado y la información en particular, Véase. ZARHi Villagra, Oscar (2010). La teoría de los mercados eficientes como garantía de una correcta fiscalización del mercado de valores en González Iturria, Marco (Editor): Regulaciones en el mercado de valores, Cuadernos de extensión jurídica 19, Universidad de los Andes, pp. 4372. Asimismo, se puede consultar a Ramírez, V. / YÁñez, G. (2010). Información de los estados financieros y periodos de Blackout: evidencia para Chile, Documento de Trabajo No 10, Serie Documentos de Trabajo, Superintendencia de Valores y Seguros, Chile. Disponible en: www.svs.cl; Lazen, V / Eguiluz, C. (2006). Conflictos de interés en servicios financieros: taxonomía y mecanismos de control regulatorio, Documentos de Trabajo No 6, Serie de Documentos de Trabajo, dic. Superintendencia de Valores y Seguros, Disponible en: www.svs. cl Asimismo se deben considerar la creación por la SVS de Reglamentos internos sobre el 
alterar la consecución de estos principios y preservar la neutralidad informativa ${ }^{13}$.

Este mecanismo se contempla en la mayor parte de las legislaciones de Derecho comparado ${ }^{14}$ aunque no de una manera unívoca. Normalmente la regulación del uso de información privilegiada se asienta en una cuestión de hecho como es la "asimetría de información" que consiste en la distinta posición que tiene un sujeto con otro en relación a determinados antecedentes. Si bien es parte de la cotidianeidad que así ocurra ${ }^{15}$, el asunto se torna relevante cuando la asimetría nace a partir del desempeño de determinados cargos o funciones, como ocurre con los administradores o directores de una sociedad anónima, sus gerentes, y quienes ocupen puestos relacionados con la operatividad de una empresa o del mercado de valores, en tanto estos necesariamente poseerán mayor información que el resto, como resultado de su propia actividad, confianza, y aun de sus derechos. Como contrapartida, a estos sujetos se les impone normalmente el deber de relevar la información esencial en un breve plazo, por medio de los conductos señalados por el legislador a estos efectos, o abstenerse de su utilización ${ }^{16}$. En otras palabras, la situación de privilegio que ostentan tiene una carga de deberes que limita su actuar, lo que les brindaría una posición inmejorable en cuanto a la posibilidad de realizar una serie de acciones con miras a obtener provecho o beneficios de las mismas, que en otras condiciones jamás hubieran realizado ${ }^{17}$.

deber de reserva, manejo de información privilegiada y operaciones sobre valores de oferta pública que afecta a la totalidad de funcionarios a la SVS.

13 Prado Puga (2003) 238-239.

14 Para un estudio sobre el particular, Véase: Informe Comisión de Hacienda, Historia de la ley 20.382, pp. 188-193. Disponible: www.bcn.cl

15 Así, por ejemplo, una persona estudiosa de una determinada materia estará ciertamente mejor preparada y amparada en un registro mayor de información que quien no lo es, lo que le permitirá tomar mejores decisiones. Si se trata del funcionamiento del mercado de valores, seguramente este sabrá qué acciones vender y cuáles comprar en el momento oportuno, mientras que otros sencillamente para actuar deberán pedir asesoría para no errar en tales operaciones. De esta forma, que existan diferencias informativas entre las personas no es algo que se pueda evitar, forma parte de los esfuerzos o situaciones personales que cada persona realiza y el derecho parte por aceptar esta situación como lícita.

16 Este deber comenzó a desarrollarse a partir de 1903 con el caso Olviver v. Olviver, en el cual la CS de Georgia (EEUU) estableció el deber de revelar (duty to disclose rule), señalando que en aquellos casos en que el director de una compañía obtenía información que otorgaba valor añadido a una acción, debido a su cargo, este tenía aquella información en comisión de confianza (in trust) para el beneficio de los accionistas.

17 La lógica de fondo que subyace a este planteamiento es que si uno o más sujetos están en condiciones de utilizar una información en el mercado a partir de determinados desempeños, funciones o cargos, ello vulnera la confianza de quienes no tienen tal posibilidad, desalentando su intención de hacer operaciones al verse en un pie de desigualdad, lo que en definitiva provoca que las demandas se retraigan y se genere una distorsión en la operatividad del mercado de valores en general. Una referencia de este fundamento lo constituye el caso Texas Gulf Sulphur o TGS (EEUU), que da nacimiento a la llamada teoría del "equal access theory”, según la cual se presume que todos los inversionistas tienen la misma información 
Se aprecia de lo anterior que no toda asimetría es repugnable a los ojos del legislador o lo que es igual, que el uso de información privilegiada es, en general, lícito, solo será ilícito si quien incurre en la conducta está tipificado como tal o es subsumible como posible sujeto responsable descrito en la normativa. Este hecho necesariamente debemos analizarlo desde las esferas filosóficas que impregnan la institución, en especial, en relación a la naturaleza jurídica que subyace a esta prohibición.

Más allá de esta discusión, la salida de este dilema ha pasado por resguardar un acceso igualitario a la información, obligando a los emisores a la entrega de aquella que se entiende esencial en un breve plazo $^{18}$, a menos que se justifique lo contrario ${ }^{19}$; y como ello no es del todo eficiente -en tanto siempre existirá un lapsus en que esa información no estará disponible al público general y solo algunos la conocerán- se ordena que aquellos que la conocen por su especial cargo o función, deban abstenerse de revelarla o utilizarla. Visto de este modo, la nota que caracteriza la regulación de esta institución se resume en la conducta de "revelar o abstenerse" ${ }^{20}$, esto es, se revela la información al público en general o el o los sujetos que la poseen en función de determinadas circunstancias se abstienen de su utilización en tanto esta última lleva consigo una injusticia inherente de su utilizador en relación al resto de los sujetos que podrían haber efectuado idénticas operaciones de haber accedido a ella ${ }^{21}$. El legislador chileno inspira la regulación normativa de esta materia justamente en los criterios antes esbozados ${ }^{22}$, aunque de una forma particularmente difusa ${ }^{23}$.

en el mercado, de manera que quien ostenta una posición de privilegio se obliga a revelar la información a fin de que todos los inversores tengan la misma posibilidad de acceder a ella, o bien abstenerse de comerciar con los valores afectados (disclose or abstain rule).

18 Véase: Arts. 9 y 10 LMV. Se agrega la Circular No 585 de la SVS que establece la obligación de informar las transacciones con acciones de la compañía realizadas por accionistas mayoritarios, directores, gerente general, liquidadores, personas relacionadas, entre otros. Asimismo, se encuentra la Norma de Carácter General No 30, que impone a las empresas la obligación de revelar información con cierta periodicidad. Sobre la eficiencia de estos mecanismos en el mercado, Véase, Zarhi Villagra (2010) 54-55.

19 Información reservada, Véase, Art. 10 inc. $3^{\circ}$ LMV.

20 Este principio fue recogido en la jurisprudencia de EEUU (Disclose or Abstain Rule). En EEUU las fuentes normativas más relevantes son la Securities Exchange Act de 1934 sobre fraude en materia de valore (secciones 10 b) y 16 b)); The insider Trading Sanction Act, de 1984; y The Insiders Trading and Securities Fraud Enforcement, de 1984.

21 Los países europeos, en general, han abrazado los mecanismos de defensa anti-insiders destinados a controlar la información privilegiada.

22 Manifestando sus dudas sobre tales razones y objetivos. Ried Undurraga (2004) 243. Para un estudio de las razones que se esgrimen a favor y en contra de la prohibición del insider Trading Véase, López BarJa de Quiroga, Jacobo (1998). El abuso de información privilegiada, El abuso de información privilegiada, en Bacigalupo, E. (Editor): Curso de Derecho Penal Económico, Madrid: Marcial Pons, pp. 336-338. Desde un punto de vista general, atendiendo los argumentos que abogan por la regulación y desregulación del uso de información privilegiada, Véase: Salah Abusleme (2005) 53-85.

23 En el mismo sentido, Véase: Ried Undurraga (2004); Guzmán Anrique (2009) 58-59. 
A partir de estas consideraciones se pueden extraer un par de conclusiones provisionales, que son relevantes para comprender lo que se expondrá posteriormente: 1 . El objeto de protección es la confianza de los actores del mercado en orden a poder actuar con información simétrica donde todos estén en un pie de igualdad, a lo menos de oportunidades para acceder a ella. 2. La regulación del uso de información privilegiada es necesaria para mantener los equilibrios y confianzas del mercado de valores. 3. Dicha regulación deber ser adecuada y eficiente para el logro de estos objetivos; 4. Si no se resguarda de manera eficiente esta institución, se corre el riesgo de vaciar de contenido el fundamento de esta regulación, cometiendo, de paso, algunas injusticias.

\section{2) REgUlaCión DEL USO DE INFORMACIÓN PRIVILEGIADA EN CHI- LE: ASPECTOS HISTÓRICOS-LEGISLATIVOS}

La regulación del uso de información privilegiada en Chile es relativamente nueva si consideramos el tiempo en que ha funcionado el mercado de valores y el Derecho societario chileno ${ }^{24}$. Se dio inicio a ella por medio de la ley No 18.045 de Mercado de Valores (1981) ${ }^{25}$ con el objeto de fomentar en el mercado los valores de equidad, el orden y la transparencia, así como asegurar la amplia difusión de la información y el aumento de la competitividad ${ }^{26}$. Se buscaba un mercado equitativo, ordenado y transparente que fomentara la consecución de un mercado eficiente, asumiendo que una prohibición del uso de la información privilegiada era lo que permitiría alcanzar tales objetivos ${ }^{27}$.

Antes de esta regulación, los socios, accionistas mayoritarios, directores y administradores de las sociedades anónimas abiertas de Chile, eran completamente libres para usar la información privilegiada de sus

24 El legislador chileno tomó estos y otros fundamentos fuertemente influenciada por la experiencia que sobre el particular existía en Derecho comparado, en especial, la de EEUU.

25 En 1840 se intentó establecer la primera bolsa de valores, la que tomó finalmente forma en 1893 con la Bolsa de Comercio de Santiago. Véase: http://www.bolsadesantiago.com/web/ bcs/historia Por su parte, en 1854 se dictó la ley de sociedades anónimas, luego incorporada en el Código de Comercio de 1865 y finalmente separada de él en 1981 al dictarse la ley 18.046 .

26 En palabras del Superintendente de Valores y Seguros de la época, el principal objetivo del nuevo sistema jurídico chileno era de asegurar la existencia de un mercado eficiente: las nuevas leyes sobre mercado de valores y sociedades anónimas tienen como objetivos principales desarrollar un mercado fuerte y eficiente, creando una mayor competencia con fuentes de inversión para los ahorrantes distintas del sistema bancario". Diario La Segunda, 5 de noviembre de 1981, p. 14, citado por Giesze (1999). Asimismo el Mensaje del Proyecto de la Ley No 18.045 reiteró estos objetivos y enfatizó que "debe tender a alentar la confianza de los inversionistas en el mercado de capitales y a fomentar la inversión en los instrumentos de ese mercado".

27 Guzmán Anrique (2009) 47-48; En el mismo sentido Giesze (1999) 800. 
compañías y especular sobre el valor de sus acciones en su propio beneficio o de terceros ${ }^{28}$.

La ley en comento, en relación a la información y su uso, estableció en su Art. 13 los cimientos de esta regulación ${ }^{29}$ al establecer la prohibición de valerse de la información reservada para obtener para sí o para otros, ventajas mediante la compra o venta de valores; y algunos deberes, tales como guardar estricta reserva respecto de la información que no ha sido divulgada oficialmente al mercado por la compañía y que pueda influir en la cotización de los valores de la misma, y velar para que sus subordinados y terceros de confianza no obtuvieren ventajas mediante la compra o venta de valores valiéndose de información reservada. Se sumaba a ello una acción consistente en la posibilidad que la persona perjudicada con estas acciones pudiera demandar perjuicios, y una sanción, en tanto que las personas que hubieren contravenido la citada disposición deberían devolver a la caja social toda utilidad obtenida a través de transacciones de valores de la sociedad.

Esta disposición presenta, a grandes rasgos, dos peculiaridades que hoy ya no se mantienen: la sanción y la concepción de información privilegiada. En cuanto a la sanción, se podría pensar que la información se entendía como parte de la propiedad del bien societario, toda vez que aquella apuntaba justamente a devolver a la "caja social" las utilidades percibidas a través de las prácticas antes descritas, de manera que la prohibición podría fundarse, en principio, en la apropiación de un bien ajeno y hacer uso del mismo ${ }^{30}$. Con todo, tal afirmación debe matizarse en tanto "cualquier persona perjudicada" con la citada conducta podía reclamarla, con lo que se aprecia también el intento de dar protección a un espectro más amplio que la sociedad en cuestión, lo que podía interpretarse como un intento de resguardo del correcto funcionamiento del mercado. En

28 Sobre la regulación del uso de información privilegiada en su evolución, Véase Informe Comisión de Hacienda, Historia de la Ley 20.382, pp. 176-206. Disponible: www.bcn.cl

29 La citada disposición concretamente señalaba: "Los directores, administradores y, en general, cualquier persona que en razón de su cargo o posición tenga acceso a información de la sociedad $y$ de sus negocios, que aún no haya sido divulgada oficialmente al mercado por la compañia en cumplimiento de lo dispuesto en la presente ley y que sea capaz de influir en la cotización de los valores de la misma, deberá guardar estricta reserva.

Asimismo, se prohíbe a las personas mencionadas en el inciso anterior, valerse de la información reservada para obtener para sí y para otros, ventajas mediante la compra o venta de valores. Ellas deberán velar para que esto tampoco ocurra a través de subordinados o terceros de su confianza.

Las personas mencionadas en el inciso primero que hayan actuado en contravención a lo establecido en este artículo deberán devolver a la caja social toda utilidad que hubieren obtenido a través de transacciones de valores de la sociedad.

Toda persona perjudicada por infracción a lo dispuesto en el presente artículo tendrá derecho a demandar indemnización en contra de las personas indicadas en el inciso primero, excepto si estaba en conocimiento de la información reservada".

30 En el mismo sentido, Ried Undurraga (2004). 
relación a la segunda, debemos destacar que además de no definir el uso de información privilegiada, la confundía con la información reservada lo que inducía a error.

En 1994 se da un giro notable en esta materia, con la ley 19.301 que incorporó el Título XXI a la Ley de Mercado de Valores denominado "De la información privilegiada". Entre las novedades que aportó esta norma se encuentran la conceptualización del "uso de la información privilegiada" en una posición más amplia que la existente hasta ese momento, señalando a las personas afectadas por la prohibición; las presunciones de quienes tienen acceso a la información privilegiada; la regulación de la actividad de los intermediarios de valores; y el establecimiento de normas de responsabilidad civil, entre otros aspectos. Por medio de dicha normativa, se intentaba asegurar la existencia de la eficiencia del mercado, la simetría de la información, la transparencia, la equidad y la igualdad de oportunidades para todos los inversionistas, la buena fe, la ética, la honestidad y la transparencia en el mercado de valores de Chile ${ }^{31}{ }^{32}$.

Este nuevo título fue posteriormente complementado por las leyes $\mathrm{No}_{s} 19.389$ (1995) y 19.705 (2000), por medio de estas se especificaron algunos de los aspectos regulados por la ley tales como la calidad de los terceros con quienes los intermediarios pueden efectuar operaciones lícitamente y los sujetos respecto de los cuales se presume que tienen acceso a información privilegiada; se modificaron algunos aspectos del mercado de valores en general y precisaron las disposiciones relativas a los negocios efectuados por los directores de las sociedades anónimas con personas relacionadas cuando tienen interés ${ }^{33}$.

31 Para ello se argumentó que el uso de la información privilegiada de sociedades anónimas y de las intenciones de transacción de fondos de pensiones o de fondos de inversión, o la manipulación de precios de mercado con recursos propios o de terceros, constituían prácticas que reducen la confianza en la equidad del sistema”. Presentación de A. Foxley, Ministro de Hacienda, Cámara de Diputados, Sesión 8 de junio de 1993 en la discusión del proyecto de ley.

32 El Superintendente de Valores y seguros de la época parte reconociendo un desequilibrio informativo al señalar que algunas personas, como los emisores e intermediario de valores y los inversionistas institucionales, disponen de una cantidad de información superior a cualquier otro agente económico a diferencia de los inversionistas particulares y público en general. Debido a este hecho, existe la necesidad de establecer una forma regulatoria que inhiba a los primeros de revelarla y menos utilizarla, mientras ella no sea divulgada oficialmente al mercado. Con ello -argumenta- se cumpliría un objetivo de participación igualitaria de oportunidad de la información. De este modo, se esgrime que una regulación adecuada perfeccionaría la transparencia del mercado y daría una mayor confianza al inversionista en general, protegiendo de paso la fe pública. Presentación del Superintendente de Valores y Seguros ante la Comisión de Hacienda del Senado.

33 Respecto de las sanciones penales, Véase, entre otros, Bustos Ramírez, Juan (1991). "Perspectivas actuales del derecho penal económico". Rev. Gaceta Jurídica 132; Hernández BAsualto, H. (2005). Perspectivas del Derecho penal económico en Chile en Persona y Sociedad, Vol. XIX pp. 101-134; PIÑa Rochefort, Juan Ignacio (2010). Algunos problemas del delito de uso de información privilegiada", en Gónzalez Iturria, Marco (Editor): Regulaciones en el 
La última reforma sobre esta materia deriva de la ley 20.382, que introduce perfeccionamientos a la normativa que regula los gobiernos corporativos de las empresas ${ }^{34}$. Resumidamente esta ley introduce modificaciones en los siguientes campos: a. Se agrega la prohibición de enajenar los valores cuando se posea información privilegiada, supuesto que había sido omitido anteriormente (Art. 165); b. Se efectúan una distinción en relación a la presunción de posesión de información, aplicable a los sujetos que se desempeñan dentro de la administración de la empresa; de la presunción de acceso a la información, aplicable a los actores que interactúan con la administración, sin ser parte de ella, lo que se traducirá en un estándar más alto para los primeros (Art. 166); c. Se modifica el inciso $2^{\circ}$ del Art. 164, cambiando el verbo rector "tener" por "poseer" y ampliando el radio de acción de aquella; y d). Se restringen aún más las operaciones que pueden realizar los intermediarios de valores, en tanto, si estos poseen información privilegiada solo podrán realizar actuaciones por cuenta de terceros no relacionados con ellos, siempre que la orden y las condiciones específicas de la operación provenga del cliente, sin asesoría ni recomendación del intermediario, y la operación se ajuste a su norma interna, establecida de conformidad al artículo 33 (Art. 165 inc. $3^{\circ}$ ). A ello debemos agregar el incremento de la autorregulación como medida de eficiencia del funcionamiento del mercado, es así que el Art. 10 inc. $2^{\circ}$ de la LMV dispone que será responsabilidad del directorio de cada entidad adoptar una norma interna que contemple los procedimientos, mecanismos de control y responsabilidades que aseguren la divulgación de la información esencial respecto de ellas mismas y de sus negocios al momento en que ocurra o llegue a su conocimiento; mientras que los arts. 16 y siguientes regulan las políticas que establezcan normas, procedimientos, mecanismos de control y responsabilidades, conforme a las cuales directores, gerentes, administradores y ejecutivos principales, así como las entidades controladas directamente por ellos o a través de terceros, podrán adquirir o enajenar valores de la sociedad o valores cuyo precio o resultado dependa o esté condicionado, en todo o en parte significativa, a la variación o evolución del precio de dichos valores.

mercado de valores, Cuadernos de extensión jurídica 19, Santiago: Universidad de los Andes, pp. 113-135.

34 Publicada en el D.O. con fecha 20 de octubre de 2009. 


\section{2) ÁMBITO DE APLICACIÓN MATERIAL DE LA NORMATIVA SOBRE USO DE LA INFORMACIÓN PRIVILEGIADA}

\section{1) SOBRE LA INFORMACIÓN PRIVILEGIADA Y LAS TIPOLOGÍAS CON- TEMPLADAS NORMATIVAMENTE}

Un examen literal del Art. 164 de la LMV ${ }^{35}$ evidencia la existencia de al menos tres tipologías de información privilegiada: dos en el primer inciso (general e información reservada) y una en el tercero (la que se posee sobre decisiones de un inversionista institucional). En efecto, la expresión "asimismo" denota que se agrega algo diferente de lo contenido en la definición previa, de manera que no podríamos entender que la información reservada se encuentre incluida en la primera definición, de así haber sido, se hubiere omitido toda referencia a ella, por innecesaria, o bien, se habría empleado una expresión adecuada para ello, como sería "por tanto", "por ejemplo", u otra expresión equivalente ${ }^{36}$. Igual cosa sucede con el inciso segundo del mismo artículo, pues el término "también", con que se inicia, denota que este se refiere a una situación diferente de las contenidas en el inciso primero pero a las cuales se la quiere equiparar en sus efectos. De este modo, si el legislador hubiera utilizado en vez de la voz "también", la expresión "se comprende, por tanto, en el concepto de información privilegiada...”, u otra semejante, podría llegarse a la hipótesis contraria, por cuanto, podría sostenerse que se alude a la información privilegiada como una categoría única, aunque con diversos componentes ${ }^{37}$.

Por consiguiente, del concepto señalado en el Art. 164, extraemos que el legislador califica como privilegiada a: 1. Cualquier información, siempre que esta: a) No haya sido divulgada al mercado; b) Se refiera a uno o varios emisores de valores, a sus negocios o a uno o varios valo-

35 Que dispone: "Para los efectos de esta ley, se entiende por información privilegiada cualquier información referida a uno o varios emisores de valores, a sus negocios o a uno o varios valores por ellos emitidos, no divulgada al mercado y cuyo conocimiento por su naturaleza, sea capaz de influir en la cotización de los valores emitidos, como asimismo, la información reservada a que se refiere el Art. 10 de esta ley.

También se entenderá por información privilegiada, la que se posee sobre decisiones de adquisición, enajenación y aceptación o rechazo de ofertas específicas de un inversionista institucional en el mercado de valores".

36 Desde otra óptica, la legislación española define información privilegiada en el Art. 81.1 de su LMV, y señala: "Se considerará información privilegiada toda información de carácter concreto que se refiera directa o indirectamente a uno o varios valores negociables o instrumentos financieros de los comprendidos dentro del ámbito de aplicación de esta ley, o a uno o varios emisores de los citados valores negociables o instrumentos financieros, que no se haya hecho pública y que, de hacerse o haberse hecho pública, podría influir o hubiera influido de manera apreciable sobre su cotización en un mercado o sistema organizado de contratación".

37 Para Raúl Varela Morgan, la afirmación anterior también se desprende y refuerza de lo señalado en el Art. 166. Véase, Varela Morgan, Raúl, Informe en Derecho No 3 Adquisición de acciones sociales: Uso de información privilegiada. MJD 153. 
res por ellos emitidos; y c) Sea relevante, en tanto que su conocimiento pueda influir en la cotización de los valores emitidos; 2. La información reservada; y 3. Aquella información que se posee sobre decisiones de adquisición, enajenación y aceptación o rechazo de ofertas específicas de un inversionista institucional en el mercado de valores.

Esta descripción provoca algunas lecturas programáticas en tanto no queda claro por qué se opta por diferenciar las informaciones en estos tres tipos, en vez de formular un solo arquetipo en que se subsuman todas las demás. Esta inquietud se evidencia de forma más clara si nos preguntamos por los elementos que configuran cada una de estas tipologías, toda vez que -tal como está redactada la norma- los requisitos para configurar los distintos topos de información privilegiada no son unívocos, sino que solo presentan algunos elementos comunes. Así, mientras la información general puede centrarse en algunos contenidos específicos (referida a uno $\mathrm{o}$ varios emisores de valores, a sus negocios o a uno o varios valores por ellos emitido), la información reservada presenta un radio más amplio ${ }^{38}$, lo que también ocurre con el último tipo también presenta un campo de acción disímil a los precedentes.

Tampoco queda claramente consignado si los dos últimos tipos de información debieran reunir con los requisitos adicionales de falta de publicidad y la potencialidad de influir en la cotización de los valores emitidos seńalados en la primera parte. Ante ello, y si bien nos inclinamos por la afirmativa considerando que se trata de elementos fundamentales de la configuración de la información privilegiada, somos conscientes de la falta de claridad que la defectuosa articulación conlleva en este punto.

Retomando los distintos objetos en que puede recaer la información, advertimos que en la primera parte se excluye la información que un sujeto posea sobre otras entidades que no sean emisoras de valores, o a operaciones que no sean encasillables en "a sus negocios o uno o varios valores por ellos emitidos". La pregunta que emerge es la siguiente: si lo protegido es la simetría de información, y la correcta operatividad del mercado de valores, ¿por qué se opta por delimitar el ámbito de aplicación a este campo, si otras informaciones también pueden afectar su funcionamiento? En relación a ello, debe considerarse que el uso de información privilegiada también podría afectar el curso de las negociaciones que la entidad emisora pueda estar llevando a cabo, o su propia marcha y, asimismo, también podría ocasionarse la afectación de otros negocios no ligados directamente con el emisor de la información, cuyo resultado lesione la práctica del mercado de valores. En la primera parte de este punto es po-

38 De acuerdo al art. 10 inc. $3^{\circ}$, se puede dar el carácter de reservado a "ciertos hechos o antecedentes que se refieran a negociaciones aún pendientes que al conocerse puedan perjudicar el interés social". 
sible apreciar el predomino de la protección del mercado de valores, en tanto minusvalora cualquier otro tipo de circunstancias o consecuencias ajenas al funcionamiento de aquel para apreciar y dimensionar la configuración de esta prohibición. En la segunda parte, sigue predominando la lógica de una conexión material que asocia el efecto que tenga el uso de una determinada información en la cotización de los valores del emisor al que le pertenece la información. Se trata de un tema complejo sobre el cual no parece existir una respuesta enteramente satisfactoria.

\section{2) ALCANCES SOBRE LOS VOCABLOS QUE CONFORMAN LA NOCIÓN DE INFORMACIÓN PRIVILEGIADA Y SU DISTINCIÓN DE OTRAS FI- GURAS AFINES}

\section{(2.2.1) Datos, información, y conocimiento}

Existen tres conceptos básicos y esenciales sobre los que no se ha prestado una mayor atención doctrinaria y que pese a su similitud, presentan diferencias sustanciales que se deben ser consideradas para configurar correctamente la noción de información privilegiada, nos referimos a los datos, la información y el conocimiento. El primero da cuenta de un conjunto de hechos discretos y objetivos sobre acontecimientos que no indican nada por sí solos. La información, en cambio, es un cúmulo de datos significativos que cambian la conducta del receptor o modifican su criterio respecto de algo, de donde se deduce que es este quien decide si el mensaje que recibe tiene relevancia suficiente. El conocimiento, a su vez, deriva de la información siendo definido como una mezcla fluida de experiencia estructurada, valores, información contextual e internalización experta que proporciona un marco para la evaluación de nuevas experiencias e información ${ }^{39}$. De este modo, para que podamos hablar de información privilegiada, esta debe basarse efectivamente en un cúmulo de datos que adquirirán mayor o menor relevancia en función de su receptor, pues no todas las personas van a valorarlos de igual manera. Los datos poseerán entidad suficiente para poder ser considerada información dependiendo del nivel de conocimiento personal sobre el objeto o materia acerca de la cual versen ${ }^{40}$, independiente de este hecho, los datos adquirirán una especial fisonomía cuando dejen de referirse a hechos aislados y

39 En las organizaciones la información normalmente queda arraigada en documentos o bases de datos, rutinas, procesos, prácticas y normas institucionales. Sobre el tema, Véase: ENTRENA Ruiz, Daniel (2006). El empleo de información privilegiada en el mercado de valores: Un estudio de su régimen administrativo sancionador, Navarra: Thomson-Civitas, pp. 52-53.

40 Desde un punto de vista técnico debemos recordar que el Diccionario de la Lengua Espańola cuando define información lo hace como la acción y efecto de informarse con el objeto de precisar o ampliar los conocimientos que se poseen sobre una materia determinada. 
sean presentados de manera completa y ordenada, de manera que en su conjunto manifiesten la existencia de una información concreta.

\section{(2.2.2) Noción de "privilegiada"}

En relación al vocablo "privilegiada" debemos considerar que aquel no se entrelaza necesariamente con el carácter de una información, sino más bien con la posición que un sujeto pueda tener sobre aquella. Si todas las personas tienen posibilidad de acceso a una determinada información de manera cierta evidentemente ella no tendrá el carácter de privilegiada, lo tendrá solo cuando un número reducido de sujetos accedan y conozcan dicha información, en otras palabras, si estos tienen un sitial ventajoso frente al resto de la comunidad.

Esta posición de privilegio se presume por el legislador en ciertos casos (Art. 166 LMV). Con todo, y debido a la modificación formulada a partir de la ley 20.382, la posición de privilegio cambia dependiendo del sujeto y cargo involucrado, así, no ocurre lo mismo respecto de quien posee un cargo de administración o dirección de un emisor de valores, que evidentemente le da acceso directo a dicha información y que conlleva el efecto innegable de informarse, de aquellos que no gozan de dicho acceso, de manera que solo tendrán tal posición de privilegio en la medida que tuvieron esta puerta de entrada ${ }^{41}$.

\section{(2.2.3) Conceptos complementarios relevantes: valores, información reservada e inversionista institucional}

Para deslindar esta disposición es preciso comprender algunas nociones que forman parte de su arquitectura, como son las de: emisores de valores, negocios, valores, información reservada e inversionista institucional. Pues bien, por emisores de valores debemos comprender a todos aquellos sujetos de derecho que emiten valores y que hacen oferta pública de ellos. Para hacer oferta pública de valores se debe inscribir tanto la entidad, como los valores y acciones en el Registro de Valores que lleva la SVS (Arts. $5^{\circ}$ y $6^{\circ} \mathrm{LMV}$ ). El emisor de valores más característico en nuestra legislación es la sociedad anónima abierta ${ }^{42}$.

En relación a los valores, es preciso remitirnos al artículo $3^{\circ}$ de la $\mathrm{LMV}^{43}$. La información reservada está descrita en el inciso $3^{\circ}$ del Art. 10

Véase: Reformas efectuadas por la Ley 20.382 en los Arts. 164 y 165 LMV.

De acuerdo al Art. $2^{\circ}$ de la LSA, las sociedades anónimas abiertas son aquellas que inscriban voluntariamente o por obligación legal sus acciones en el Registro de Valores.

43 Que prescribe: "Para los efectos de esta ley, se entenderá por valores cualesquiera titulos transferibles incluyendo acciones, opciones a la compra y venta de acciones, bonos, debentures, cuotas de fondos mutuos, planes de ahorro, efectos de comercio, y, en general, todo título de crédito o de inversión. 
y dice relación con la información referida a ciertos hechos o antecedentes de negociaciones aún pendientes que al conocerse puedan perjudicar el interés social ${ }^{44}$. Se trata de información esencial que en principio debe revelarse ${ }^{45}$ pero que como excepción, cumpliendo ciertos requisitos, se reservará de difusión. El carácter de reservada ha de otorgarse con la aprobación de las tres cuartas partes de los directores en ejercicio, y tratándose de emisores no administrados por un directorio u otro órgano colegiado, tal decisión habrá de tomarse por todos sus administradores. Estas deberán ser comunicadas a la Superintendencia al día siguiente a la adopción por los medios tecnológicos que a estos efectos habilite la referida entidad $^{46}$. Es preciso considerar que de conformidad con el inciso final de esta disposición, los que dolosa o culpablemente califiquen o concurran con su voto favorable a declarar como reservado un hecho o antecedente, de aquellos que se refiere el inciso tercero de este artículo, responderán en la forma y términos establecidos en el Art. 55 de esta ley.

Por inversionista institucional debemos comprender a los bancos, sociedades financieras, compañías de seguros, entidades nacionales de reaseguro y administradoras de fondos autorizados por ley (Art. $4^{\circ}$ bis LMV). También tendrán ese carácter, las entidades que señale la Superintendencia mediante una norma de carácter general, siempre que se cumplan las siguientes condiciones copulativas: a) que el giro principal de las entidades sea la realización de inversiones financieras o en activos financieros, con fondos de terceros; b) que el volumen de transacciones, naturaleza de sus activos u otras características, permita calificar de relevante su participación en el mercado. Estas entidades, por su especial naturaleza, se podrán encontrar sometidas a una doble regulación ${ }^{47}$, lo que se debe con-

Las disposiciones de la presente ley no se aplican a los valores emitidos o garantizados por el Estado, por las instituciones públicas centralizadas o descentralizadas y por el Banco Central de Chile".

44 Esta regulación tiene como antecedente el emblemático caso de EEUU conocido como TGS en que la Corte de dicho país reconoció a la entidad su derecho a mantener la confidencialidad de aquella información que aún no estaba lista para ser revelada al mercado. En virtud de ello, la información que debe revelarse al mercado es aquella que esté lista o madura, considerando como tal aquella en que exista una certeza razonable y en que no sea necesario mantener en secreto para el éxito de las futuras negociaciones.

Véase: Arts. 9 y 10 LMV.

Modificación efectuada a partir de la ley 20.382.

Así, por ejemplo, en relación a las Administradoras de Fondos de Pensiones (AFP), actual Superintendencia de Pensiones (SIP), esto se evidencia en el aspecto subjetivo, en tanto las personas que en razón del cargo o posición tienen acceso a información de las inversiones de alguno de los fondos, se les aplica tanto el estatuto general, contenido en la LMV, como las normas especiales que se encuentran dentro del Título XIV del DL 3500, sobre conflictos de Interés. Dichas normas conducen a establecer que la finalidad perseguida fue la de replicar el estatuto de la información privilegiada contenido en la LMV en el DL 3500, atendida la importancia que el legislador le atribuyó a la actividad de la AFP y la necesidad de resguardar la rentabilidad y seguridad de estos fondos, los que podrían verse lesionados con ocasión del uso indebido de información privilegiada a terceros. 
siderar a efectos de determinar el organismo que inicia la correspondiente investigación ${ }^{48}$.

\section{3) ELEMENTOS INTEGRANTES DE LA NOCIÓN DE INFORMACIÓN PRI- VILEGIADA Y SU ÁMBITO MATERIAL DE APLICACIÓN}

El Art. 164 de la LMV, dispone que la información, para ser calificada de privilegiada, en su acepción más amplia, deberá: 1) Tratarse de cualquier información; 2) Referirse a uno o varios emisores de valores, a sus negocios o a uno o varios de los valores por ellos emitidos; 3) No estar divulgada al mercado ${ }^{49}$; y 4) Ser trascendente, esto es, capaz de influir en la cotización de los valores asociados al emisor. Analizaremos a continuación cada uno de estos elementos:

\section{(2.3.1) Carácter de información}

Esta institución exige que se trate de una información con lo que se excluyen los simples datos. Si bien el legislador emplea el vocablo "cualquier información", lo cierto es que tal laxitud debe leerse con precaución, en tanto en estricto derecho no cualquier información puede ser catalogada como privilegiada, para ello es preciso que se reúnan las condiciones establecidas en el Art. 164 LMV, esto es, referirse a uno o varios emisores de valores, a sus negocios o a uno o varios de los valores por ellos emitidos; y sumar otras que, si bien no están expresamente establecidas, se subentienden de la propia naturaleza de esta materia como ocurre con la concreción ${ }^{50}$.

48 Frente a tal inquietud, la Corte de Apelaciones de Santiago, con fecha 31 de marzo de 2008, en causa "Reyes Miguel c/ Superintendencia de Valores y Seguros", pronunciándose sobre el particular señaló que: "No resulta procedente iniciar una nueva investigación administrativa sobre los mismos hechos por otro organismo fiscalizador -como en este caso lo es la Superintendencia de Valores y Seguros- aunque este sea competente para vigilar el cumplimiento de las normas sobre uso de información privilegiada contenidas en la Ley 18.045 y esté, eventualmente, dotado de mayores facultades que le permitirían reunir una mejor prueba para acreditar la infracción que no pudo establecer el otro organismo fiscalizador, si la conducta ya fue investigada por una agencia fiscalizadora y esta emitió su pronunciamiento; toda vez que ello implicaría efectuar una doble persecución por parte del Estado respecto de unos mismos hechos, lo que atenta contra el principio del Non bis in ídem y conlleva el riesgo de tener que enfrentar decisiones contradictorias.

49 El derogado artículo 13 de la ley de Mercado de valores exigía que la información haya sido divulgada "oficialmente" al mercado. De acuerdo a lo antes expuesto podemos señalar que no se considerará información privilegiada aquella que haya sido comunicada al mercado por algún medio idóneo, pues el artículo en estudio no exige la divulgación oficial de la información. Será labor del juez la valoración en cada caso y determinar los parámetros para poder considerar que determinada información se ha hecho pública y que a su vez el mercado ha asimilado como tal dicha circunstancia.

50 La mayor parte de la doctrina y legislación están contestes en este requisito de manera general. Véase, entre otros, Entrena Diaz (2006). Salah Abusleme (2005) 33-34. 
En efecto, la información debe provenir de hechos reales o con$\operatorname{cretos}^{51}$ (no abstractos), entendiendo por el primero algo que es demostrable, y por el segundo algo que puede ser identificado como un pensamiento, juicio o concepto ${ }^{52}$. No encaja en esta descripción aquella información relativa al mercado en general pronosticando un alza o baja de las cotizaciones en su conjunto, o simples rumores que puedan existir en el mercado, por tratarse de meras hipótesis; en tal sentido, se requiere que aquello sea cierto o pueda serlo en el futuro, y su veracidad pueda ser comprobada fácilmente. Así, por ejemplo, si se conoce que va a tener lugar una OPA, aunque no se conozca el precio de la oferta, se tratará de una información concreta que puede alcanzar la calificación de privile$\operatorname{giada}^{53}$.

Por otra parte se debe considerar que una interpretación errada de la norma podría entender que el legislador pretendió hacerse cargo de la concreción aludiendo a materias específicas, como son: emisores, sus negocios o sus valores, pero ella difícilmente será considerada plausible, toda vez que puede ocurrir que exista una información abstracta sobre cualquiera de dichos ámbitos y no se configure una información privilegiada.

La relevancia o esencialidad que debe reunir la información tampoco es baladí. Al respecto es preciso engarzar esta calificación con los Arts. $9^{\circ}$ y $10^{\circ}$ de la LMV que disponen que la inscripción en el Registro de Valores obliga al emisor a divulgar en forma veraz, suficiente y oportuna toda información "esencial" respecto de sí mismo, de los valores ofrecidos y de la oferta, entendiendo por tal, aquella que un hombre juicioso consideraría importante para sus decisiones de inversión. De este modo, no cualquier información puede ser considerada privilegiada, para ello es preciso que la información posea el carácter de esencial, toda vez que es esta la que se intenta proteger por medio de su obligatoria divulgación o la prohibición de su utilización o difusión ${ }^{54}$.

51 El Diccionario de la Lengua Española nos dice que el término "concreto" se refiere "a cualquier objeto considerado en sí mismo, particularmente en oposición a lo abstracto o general, con exclusión de cuanto puede serle extrańo o accesorio", de manera que no es concreto aquella información de carácter general o abstracto que se refiera a activos o emisores de activos.

52 Entrena Ruiz (2006) 56.

53 Desde esta perspectiva, existen determinados tipos de información cuyo nivel de concreción es incuestionable, como ocurre respecto de la información relativa a operaciones sobre activos de empresas cuya realización esté proyectada, mientras en otros casos, no ocurre algo similar. Si bien para determinar tal alcance, necesariamente deberemos acudir al requerimiento de relevancia, consideramos que este no es suficiente para desprendernos de este carácter, en tanto se apunta a cuestiones diversas y complementarias entre sí, por lo que estimamos que no es prudente la redacción de esta norma que, para delimitar el ámbito de aplicación de la información privilegiada, comienza por señalar que se trata de "cualquier información", pues con ello se desprovee injustificadamente de un requisito crucial al intérprete.

54 La información financiera que deben presentar las sociedades que efectúan oferta pública de valores en el mercado chileno se encuentra regulada principalmente a partir de la Ley 
La relevancia que requiere la información para ser calificada de tal, puede dimensionarse al comprender esta noción desde una óptica global, en tanto el Art. 164 requiere que esta información "sea capaz de influir" en la cotización de los valores emitidos, y evidentemente no "cualquier" información puede provocar tal efecto. Debido a lo anterior, también aquí estimamos será necesario introducir modificaciones a la construcción normativa, con el objeto de brindar una calificación y un contenido más exacto de la noción de "información privilegiada" y facilitar, de este modo, su correcta delimitación e interpretación ${ }^{55}$.

\section{(2.3.2) Ámbito objetivo: Información sobre emisores de valores, sus negocios o sus valores}

De acuerdo a la normativa, la información puede estar referida tanto a un sujeto (emisor de valores), como a un objeto (negocios o valores emitidos por los emisores). Ya nos hemos referido a la noción de valores por lo que nos remitimos a lo señalado. En relación al "emisor", si bien el legislador no conceptualiza tal noción, debemos entender que solo los emisores de valores de oferta pública que hayan sido inscritas en el Registro de Valores podrán hacer oferta pública de Valores y estarán regidos por la LMV, frente a ello debe recordarse que las sociedades anónimas abiertas están obligadas a tal actuar ${ }^{56}$, en los términos señalados en el Art. $3^{\circ}$ de la $\mathrm{LMV}^{57}$, mientras otras entidades están facultadas a hacerlo (Art. 5 LMV). Los negocios tampoco están definidos por la ley, pero habría que entender como tales cualquier trabajo o materia de una ocupación

18.046 (LSA) y la normativa emitida al respecto por la SVS. En este sentido, cabe mencionar la Norma de Carácter General No 30 (NCG No30); y la Circular No 501, que instruye sobre el contenido y la forma de los informes financieros de las sociedades inscritas en el Registro de Valores de la SVS; así como otras circulares que estipulan el tratamiento contable de determinadas materias.

55 Aún a falta de enunciación legislativa, los tribunales si se han referido a esta característica. Así el fallo pronunciado por la CA de Santiago en causa "Banco de Chile v. SVS", se seńaló que la información "no era precisa, real, ni determinada", al no existir una voluntad claramente manifestada por parte de la sociedad Quińenco SA de comprar el 8\% de las acciones del Banco Chile a un precio determinado.

56 Art. $2^{\circ}$ Ley No 18.046.

57 En tal sentido debemos recordar que el Art. 50 de la LMV dispone que la SVS llevará un Registro de Valores donde se deberán inscribir: a. Los emisores de valores; b. Los valores que sean objeto de una oferta pública; c. Las acciones de las SA. Que tengan 500 o más accionistas o, a lo menos, el $10 \%$ de su capital suscrito pertenezca a un mínimo de 100 accionistas, excluidos los que individualmente o a través de otras personas naturales o jurídicas, excedan dicho porcentaje; y d) Las acciones emitidas por sociedades anónimas que voluntariamente así lo soliciten o que por obligación legal deban registrarlas. La solicitud de inscripción de un emisor en el registro de valores deberá estar necesariamente acompańada de una solicitud de inscripción de los valores que dicho emisor ofrecerá públicamente. Sin embargo, no estarán obligados a ofrecer los valores inscritos sino hasta después que transcurra un año desde su registro. Esta disposición debe conjugarse con el Art. $2^{\circ}$ de la LSA. 
lucrativa de interés del emisor de valores ${ }^{58}$, desde un sentido amplio de su quehacer.

El punto de inflexión de esta delimitación se encuentra en discernir en qué grado o medida debe la información estar referida a estos factores para ser considerada como privilegiada. En otras palabras, la información ¿debe estar directamente vinculada a alguna de las tres nociones señaladas, o estarlo también indirectamente? Para responder tal pregunta necesariamente habrán que considerarse otros elementos que debe reunir la información, como los aludidos caracteres de concreción y relevancia, de modo tal que si la información se encuentra referida indirectamente a alguno de los criterios expuestos deberá gozar de ambas características. Lo relevante no es que la información esté referida "directa o indirectamente" a alguno de estos elementos, sino más bien que su referencia sea concreta y que afecte la cotización de los valores, de modo que su utilización pueda posicionar a una persona en una situación de ventaja frente al resto de los inversores, ello implica sostener que lo importante son las causas y consecuencias de esta relación y ámbito de aplicación más que el grado de la misma.

Volvemos sobre la interrogante de saber por qué se opta por un ámbito de aplicación restringido, esto es, referido solo a los tres factores antes seńalados, en tanto, en principio, nada obsta que se pueda catalogar de privilegiada otras informaciones, tal como lo han hecho otras legislaciones $^{59}$.

\section{(2.3.3) Información no pública}

Para calificar la información como privilegiada, el legislador exige que ella "no haya sido divulgada al mercado". Esto tiene una justificación

58 Al efecto, el Diccionario de la Real Academia de la Lengua Española dispone: "negocio (del lat. negotium) m. Cualquier ocupación, quehacer, o trabajo. | 2. Dependencia, pretensión, tratado o agencia. $\mid 3$. Todo lo que es objeto o materia de una ocupación lucrativa o de interés. | 4. Acción y efecto de negociar. | 5. Utilidad o interés que se logra en lo que se trata, comercia o pretende. |6. Local en que se negocia o comercia. $\mid 7$. V. agente, encargado, hombre de negocios. | 8. fig. V. alma del negocio. | 9. Der. V. gestor de negocios. | de mala digestión. fig. y fam. El que es dificultoso. | jurídico. Acto de una o más voluntades que pretende algún efecto jurídico reconocido por la ley. | redondo. fig. y fam. El muy ventajoso y que sale a medida del deseo. | agitarse un negocio. Fr. Agitarse una cuestión. | desempatar un negocio. fr. fig. y fam. Ponerlo a flote, aclarando las dudas y dificultades que tenía. | evacuar uno un negocio. fr. fam. Finalizarlo, salir de él, concluirlo. | hacer uno su negocio. fr. Sacar de un asunto el provecho que puede, sin otra mira que el interés propio. | 2. Hacer un lucro indebido en los asuntos de otro que le están encomendados".

59 Si bien por largo tiempo la prohibición en el derecho norteamericano se entendía referida solo a acciones, dado el requisito de relación fiduciaria que debe unir a los corporate insiders con los accionistas, con el paso del tiempo, tal ámbito se ha ampliado a otros instrumentos tales como los opciones o con cualquier otro instrumento derivativo estando. Sobre el tema, véase: Ried Undurraga (2004) 462; GuZmán Anrique (2009) 46. 
lógica: si las operaciones se realizan sobre la base de una información que se entiende pública, entonces no existe ninguna posición de privilegio, y por ende, mal podría ser calificada la información como privilegiada pues la información pudo ser adquirida por todos los intervensionistas y participantes del mercado en igualdad de condiciones, con lo que las simetrías y equilibrios se respetan. Se trata del elemento más definitorio de la información privilegiada, en tanto, si la información reúne todos los elementos, menos este, claramente no se encontrará en dicho sitial.

Con todo, es preciso comprender que el asunto no se encuentra tanto en su carácter de publicidad, como en el acceso que se tenga de la información, en tanto, su difusión podrá ser más o menos extensiva dependiendo de los canales de información y la eficacia que estos tengan al efecto $^{60}$. Para despejar esta variable, debemos responder entonces ¿`cómo la información se pone a disposición del mercado o público general? La respuesta necesariamente va de la mano de las obligaciones que tienen los emisores $^{61}$.

En efecto, el artículo en comento debe interpretarse armónicamente con los artículos 5, 6, 9 y 10 de la misma ley. Los primeros establecen la obligación de inscripción en el Registro de Valores, señalando al efecto que la Superintendencia llevará un Registro de Valores que estará a disposición del público. En tal Registro se deberán inscribir: a) Los emisores de valores de oferta pública; b) Los valores que sean objeto de oferta pública; c) Las acciones de las sociedades anónimas que tengan 500 o más accionistas o, al menos, el $10 \%$ de su capital suscrito pertenezca a un mínimo de 100 accionistas, excluidos los que individualmente o a través de otras personas naturales o jurídicas, excedan dicho porcentaje ${ }^{62}$; y d) Las acciones emitidas por sociedades anónimas que voluntariamente así lo soliciten o que por obligación legal deban registrarlas. La solicitud de inscripción

60 Por ello algunos autores proponen sustituir el concepto de publicidad por el de accesibilidad para el mercado con independencia de la forma en que llegue este. Véase: Hernández SAINZ, Esther (1998). "La prohibición de los abusos de información privilegiada en el Derecho del Mercado de Valores francés", Revista de Derecho Bancario y Bursátil 71.

61 Podría suceder que una información difundida oficialmente no llegue al público. Para ello debe tenerse presente que no toda información que repercute en el precio de los activos se encuentra inscrita, pues mientras la información no sea divulgada no puede sostenerse que aquella sea pública. Esta objeción justifica el establecimiento de períodos de espera o waitings periods durante los cuales está prohibido operar con información que no se hubiese publicitado. Así, el American Stock Exchange recomienda un plazo de entre 24 y 48 horas para poder operar desde su publicación. Sobre el tema, véase. Gómez Iniesta, Carlos (1997). La utilización abusiva de información privilegiada en el mercado de valores, Madrid: McGraw-Hill, pp. 130 -131; Hernández SAINZ (1998) 71, quien propone sustituir el concepto de publicidad por el de accesibilidad para el mercado, con independencia de la forma en que llegue este.

62 De acuerdo al Art. $6^{\circ}$, la inscripción de las acciones a que se refiere esta letra, deberá efectuarse dentro de los sesenta días siguientes a la fecha en que se haya cumplido alguno de los requisitos allí mencionados. 
de un emisor en el registro de valores deberá estar necesariamente acompańada de una solicitud de inscripción de los valores que dicho emisor ofrecerá públicamente. No estarán obligados a ofrecer los valores inscritos sino hasta después que trascurra un año desde su registro. Por su parte, el Art. $6^{\circ}$ dispone que solo podrá hacerse oferta pública de valores cuando estos y su emisor, hayan sido inscritos en el registro de valores ${ }^{63}$.

Seguidamente se expone la posibilidad que una información tenga el carácter de reservado, materia a la que ya nos hemos referido. En tal sentido, debemos advertir que esta materia liga con las obligaciones que recaen en los directores de una compañía, como integrantes del máximo órgano de administración, las que tienen su fundamento último en la circunstancia de tratarse de personas que han recibido de otras (junta de accionistas) un encargo de confianza. Sobre el particular, el Art. 43 de la LSA dispone que los directores están obligados a "guardar reserva", es decir, a no comunicar ni revelar los negocios de la sociedad y de la información social a que tengan acceso en razón de su cargo y que no haya sido divulgada oficialmente ${ }^{64}$ por la compañía ${ }^{65}$.

Ahora bien, en el caso de las sociedades anónimas abiertas, se entenderá que se ha producido dicha divulgación cuando la información

63 A su vez, el Art. 9o señala que la inscripción en el Registro de Valores obliga al emisor a divulgar en forma veraz, suficiente y oportuna toda información esencial respecto de sí mismo, de los valores ofrecidos y de la oferta, entendiendo por información esencial aquella que un hombre juicioso consideraría importante para sus decisiones sobre inversión. Asimismo, el Art. $10^{\circ}$ prescribe sobre la información continua y reservada, que las entidades inscritas en el Registro de Valores quedarán sujetas a esta ley y a sus normas complementarias y deberán proporcionar la información que establece la ley a la Superintendencia y al público en general con la periodicidad, publicidad y en la forma que la Superintendencia determine por norma de carácter general. Igualmente, y sin perjuicio de lo dispuesto en el inciso anterior, las entidades comprendidas en él deberán divulgar en forma veraz, suficiente y oportuna, todo hecho o información esencial respecto de ellas mismas y de sus negocios al momento que él ocurra o llegue a su conocimiento. Será responsabilidad del directorio de cada entidad adoptar una norma interna que contemple los procedimientos, mecanismos de control y responsabilidades que asegure dicha divulgación. La norma respectiva, deberá ajustarse a la norma de carácter general que dicte la Superintendencia. Esta última parte fue introducida por la modificación de la ley 20.382, sobre gobiernos corporativos.

64 Nótese que se sigue empleando la calificación de "oficialmente" para referirse a la divulgación de la información, cuestión que admite discusión, en tanto debiera pensarse que se trata de una reminiscencia derivada de las normas que regulaba esta materia en la antigua LMV, específicamente su Art. 13 que requería de tal oficialidad, pero que luego fue modificada precisamente en el sentido contrario. En este mismo sentido, Véase. AlCalde RodríGUEz (2000) 11-28. Si bien esta tesis puede ser derribada si se piensa que la ley en comento fue también modificada por la ley 20.382 y ninguna modificación se efectuó en tal sentido, seguimos pensando que se trata de un despiste del legislador, pues ninguna explicación sostenible podría argumentarse para explicar esta diferenciación.

65 De acuerdo al inciso final de esta disposición, no regirá esta obligación cuando la reserva lesione el interés social o se refiera a hechos u omisiones constitutivas de infracción de los estatutos sociales, de las leyes o de la normativa dictada por la Superintendencia en el ejercicio de sus atribuciones. 
se haya dado a conocer mediante los sistemas de información al mercado previstos por la Superintendencia, de acuerdo al Art. 10 de la LMV, o bajo otra modalidad compatible con los dispuesto en el Art. 46 de la LSA $^{66}$. En tal sentido, si una OPA se comunica solo a los directores de una sociedad anónima, estos dispondrán de una información privilegiada, pero si antes o conjuntamente con ello, los medios de comunicación difunden la alta probabilidad de que ello sí ocurra, tal información perderá tal carácter pues se tratará de una información de público acceso y conocimiento, sobre todo esa información ha sido difundida en un medio de comunicación de amplio espectro. Ello, bajo la lógica que el legislador no exige que la información sea difundida por los conductos oficiales o institucionales ${ }^{67}$, sino simplemente que sea traslada al público desde un punto de vista general, por lo que para resolver la cuestión, tendrá importancia el medio de difusión empleado y su ámbito de acción.

En este punto es preciso analizar el fallo pronunciado por la CS con fecha 27 de octubre de 2005, en la causa "Hurtado Vicuña, Juan y otros c/ Superintendencia de Valores y Seguros". El recurso lo interpuso la Superintendencia con el objeto de dejar sin efecto la sentencia pronunciada por la Corte de Apelaciones de Santiago, que confirmó la de primera instancia, del Vigésimo Juzgado Civil de la misma ciudad. Este último fallo había acogido la reclamación de multa y, en consecuencia, había dejado sin efecto en todas sus partes la Resolución Exenta No166, de 8 de mayo de 2001, dictada por la SVS, por infracción al Art. 165 de la Ley $18.045^{68}$, que había aplicado una multa de 1.000 UF a los Sres. Juan Hurtado Vicuña, Eduardo Fernández León, José Antonio Garcés Silva, Juan José Mac Auliffe Granillo, Patricio Parodi Gil, Carlos Eugenio Lavín García Huidobro y Carlos Délano Abbot, por la infracción cometida ${ }^{69}$.

66 Esta última disposición señala que el directorio deberá proporcionar a los accionistas y al público, las informaciones suficientes, fidedignas y oportunas que la ley y, en su caso, la $\mathrm{Su}$ perintendencia determinen respecto de la situación legal, económica y financiera de la sociedad. En estas sociedades será responsabilidad del directorio adoptar las medidas apropiadas para evitar que la información referida en el inciso anterior de la norma en cita sea divulgada a personas distintas de aquellas que por su cargo, posición o actividad en la sociedad deban conocer dicha información, antes de ser puesta a disposición de los accionistas y el público. Se entenderá que se cumple con tal requisito cuando simultáneamente a dicha divulgación se proporcione la misma documentación o presentaciones al público conforme a la norma de carácter general que dicte la Superintendencia. Esta obligación de información señalada es sin perjuicio de lo establecido en los Arts. $9^{\circ}$ y 10 de la LMV (inc. Final. Art. 46 LSA).

67 En un principio, la LMV requería que la entrega de la información se realizara por conductos oficiales.

68 Véase: http://www.svs.cl/sitio/mercados/doc/res_166_2001.pdf

69 En la Resolución reclamada, la SVS les reprocha a los sancionados el haber adquirido valores sobre los cuales se les atribuye haber poseído información privilegiada. Los hechos que configuran la infracción son los siguientes: El directorio de Quińenco S.A. celebró una sesión con fecha 1 de diciembre de 2000, en la cual Andrónico Luksic Craig propuso que se 
La sentencia da la razón a la SVS concluyendo que los actores utilizaron indebidamente el conocimiento que poseían respecto de la próxima compra de acciones por parte del Grupo Luksic, información que revestía el carácter de privilegiada, pues ella no había sido aún divulgada al mercado, por lo que no era pública ni de conocimiento del inversionista general y representaba para quien la conocía una situación de privilegio que le imponía ciertos deberes de conducta, la que, por lo demás, condicionó y determinó la actuación de aquellos en términos tales que no habrían actuado de la manera que lo hicieron, de no haber conocido la aludida información y acarreando como efecto que el precio bursátil aumentara por acción. Por lo anterior, estiman que al desconocerse por los sentenciadores de segundo grado el carácter de privilegiada de la información de que dispusieron los demandantes al día 4 de diciembre de 2000, fecha en que se lanzó la oferta de compra de acciones por el Grupo Luksic, se incurrió en los errores de derecho que se han denunciado, especialmente de los artículos 164 y 165 de la Ley No 18.045, sobre Mercado de Valores, con influencia sustancial en lo dispositivo del fallo impugnado, por lo que se acoge el recurso de casación en el fondo deducido por la demandada ${ }^{70}$.

realizara una oferta pública para comprar al menos un $8 \%$ del capital accionario del Banco de Chile (del cual Quińenco era accionista), a un precio de $\$ 50$ por acción, previa conversación con los miembros del pacto controlador de dicha entidad bancaria (Grupo Penta) del cual formaban parte los demandantes de autos, por lo cual, ese mismo día se lo comunicaron a los demandantes Sres. Délano y Lavín, quienes, ante ello solicitaron plazo hasta el lunes 4 de diciembre para emitir un pronunciamiento al respecto, plazo que fue aceptado por los oferentes, por lo que ambas partes decidieron reunirse el día 5 de diciembre. Anticipándose a todo ello, el día 3 de diciembre se reunieron los señores Eduardo Fernández León, Carlos Lavín y Patricio Parodi Gil, Juan Hurtado Vicuńa, Juan José Auliffe, Carlos Délano Abbot y Antonio Garcés Silva, todos ellos vinculados al grupo controlador del Banco de Chile y decidieron comprar acciones de dicho banco el día lunes 4 de diciembre lo que efectivamente hicieron ese día.

70 En lo medular, sentenció: $20^{\circ}$ ) Que, definido, entonces, lo que debe entenderse por información privilegiada, debe determinarse ahora cuando el uso de la misma es indebido, que es precisamente lo que se les reprocha a los actores. Para ello resulta necesario aclarar que no cualquier conocimiento de información es reprochable, pues muchas veces resulta inevitable el conocimiento previo por pequeños grupos de inversores, de ciertas decisiones de compras o ventas de acciones, es más, ello ocurre con cierta habitualidad; sin embargo, lo censurable es el hecho de valerse, de servirse, de sacar provecho individual de la misma, sea obteniendo beneficios indebidos o evitando pérdidas económicas (...). 220 ) Que en el caso específico materia de este juicio, cabe remarcar, tal como se señaló con anterioridad, a través de la conversación sostenida entre Andrónico Luksic Craig, Francisco Pérez Mackenna, Leonidas Vial, y los demandantes Carlos Eugenio Lavín García Huidobro y Carlos Délano, que estos últimos tuvieron conocimiento de "cualquier información" atinente a los negocios "de uno o varios emisores de valores o a uno o varios valores por ellos emitidos", concretamente, a ciertos negocios de Quiñenco S.A., a las acciones del Banco de Chile que esta sociedad poseía, y al valor de estas en la oferta de compra que se lanzaría días después, información que no fue divulgada con anticipación al mercado, por lo que los actores, por esta última circunstancia, se encontraban en una situación de privilegio respecto de los demás inversores, lo que determinó, asimismo, un alza en el precio de dichas acciones, las que alcanzaron un valor de $\$ 50(\ldots)$ ". 


\section{(2.3.4) Información trascendente o relevante}

Para que la información sea calificada como privilegiada esta debe ser trascendente de manera tal que de hacerse pública tal información esta podría influir de manera considerable o apreciable en el precio de los activos emitidos ${ }^{71}$. Se vislumbran varias cuestiones ligadas a este asunto de no fácil respuesta, como son: ¿Deben ser previstos por el sujeto los efectos en comento antes de utilizar la información? (elemento subjetivo); ¿por qué, si el ámbito de aplicación de esta disposición alude a tres posibles fuentes: emisor, negocios y valores emitidos por el emisor, para delimitar la información privilegiada, solo hace referencia como efecto a uno de estos: influencia en la cotización de los valores?; y ¿̨ajo qué criterios se puede determinar que la información puede llegar a incidir de forma apreciable en la cotización de los activos y qué se entiende por tal?

Sobre este último punto, debemos considerar que no se exige un grado de influencia en particular, ni siquiera que tal influencia efectivamente ocurra, el legislador solo exige para la configuración de esta institución, la potencialidad de que así pueda suceder. En tal sentido, resulta relevante conocer el fallo pronunciado por la CS, que con fecha 26 de julio de 2007, en causa "Elesur S.A. C/ Superintendencia de Valores y Seguros" (reclamación Art. 30 DL 3.518), que resolviendo un recurso de casación en la forma y en el fondo contra la sentencia pronunciada por la Corte de Apelaciones de Santiago ${ }^{72}$, a estos efectos señaló:

“(...) Para que exista información privilegiada no es requisito que esta efectivamente influya en el mercado, sino únicamente que tenga la capacidad para hacerlo, que posea la aptitud para ello, y en el caso cabía la posibilidad cierta del cumplimiento del contrato de opción, pues de no ser así carecería de todo sentido su inclusión en la alianza estratégica que nos ocupa (...)".

Por influencia habrá que entender que esta información tenga alguna consecuencia en la mayor o menor valoración del valor transado lo que puede leerse en las alteraciones que ocurran en los precios de las acciones sea subiéndolo o bajándolo. Un número de situaciones diversas pueden afectar los precios de estos instrumentos, por ejemplo, decisiones internas en relación al personal, distribución de dividendos, resultados de litigios

71 Sobre el tema, Véase NCG No 30, de la SVS, Sección II, apartado b y su aplicación por parte de la SVS. http://www.svs.cl

72 Tal sentencia revocó la de primer grado que había acogido la reclamación interpuesta por su parte en contra de la resolución de la SVS que aplicó una multa de cien mil unidades de fomento por infracción a los artículos 164 y 165 de la Ley No 18.045, con costas; y, en definitiva, la rechazó manteniendo así vigente lo resuelto por la SVS reclamación. 
relevantes, reputación de la empresa, situación laboral de los trabajadores, las potenciales fusiones o absorciones, OPAS, en general, toda información que pueda interferir en los precios del mercado y las decisiones de los emisores ${ }^{73}$.

La cuestión es determinar cómo se reaccionaría frente a lo que no se conoce, en tal sentido debemos distinguir entre la información interna de la empresa que puede afectar esta cotización (como ocurriría con su situación patrimonial o financiera o las perspectivas de desarrollo mediante, por ejemplo, el lanzamiento de nuevos productos); e información externa a la propia empresa, que también puede influir la cotización de sus activos (como ocurre con las nuevas medidas que se adopten legislativamente para las empresas de un sector determinado, ejemplo, relacionadas con temas medioambientales). En principio, únicamente el primer tipo de información es relevante para los efectos de calificarla como privilegiada, pero también existen ciertas informaciones de carácter externo que puede tener este carácter, como ocurre con las OPAS que se lanzan sobre una empresa, la fusión con otras sociedades, el proyecto de una nueva regulación de un sector, e incluso la llegada de un nuevo partido político al gobierno de un país en que se posea intereses estratégicos. El asunto es complejo, pues se conecta con el tipo de sujeto receptor de dicha información que puede ostentar un privilegio en relación al resto ${ }^{74}$.

Dada la amplitud de aristas que recaen sobre este tema normalmente se ha debido zanjar en los tribunales de justicia ${ }^{75}$. En base a ello, somos partidarios de establecer un marco normativo que sirva de modelo en la evaluación de la incidencia sobre el precio de los activos, los que debieran ser utilizables para calibrar si la información va a repercutir sobre el precio de los activos. Entre ellos podrían encontrarse: la magnitud del hecho en relación con la actividad global de la empresa; la relevancia de la información de acuerdo con los principales factores que pueden afectar al precio del instrumento financiero; la fiabilidad de la fuente y todas las variables de mercado que afectan al instrumento financiero en cuestión. Igualmente, puede servir como criterio el hecho que la misma informa-

73 Entrada Ruiz (2006) 64.

74 En tal sentido, un insiders obtendrá información, por ejemplo, sobre una OPA, pero no podríamos sostener el mismo predicamento en relación a nuevas legislaciones pues esta información normalmente es de público conocimiento; así como también ocurre con las encuestas políticas que podrían ser detectadas con anticipación por un grupo más reducido y no necesariamente cercano a la empresa emisora de activos.

75 En este contexto, EEUU sentó tempranamente que la información es lo suficientemente relevante para influir en el precio de los activos cuando de haberse hecho pública hubiese afectado de modo decisivo a cualquier tipo de inversor, desde el más arriesgado al más conservador (CASO: SEC vs Texas Gulf Sulphure, 1968). Otros, en cambio, han intentado formular ciertos criterios (Ej. Juicios de probabilidad) para determinar cuándo la información de hacerse pública afectaría decisivamente a la cotización de los activos, lo que obliga a revisar caso por caso. Véase: Gómez InIESTA (1997) 126-127. 
ción hubiese provocado en el pasado un efecto significativo sobre los precios, si existen informes de analistas que mantengan que dicha información es esencialmente sensible o si el emisor ha considerado en otras ocasiones que dicha clase de información es privilegiada ${ }^{76}$.

A estos efectos, debemos partir por consensuar que la repercusión de la información en la cotización de los activos es un concepto jurídico indeterminado ${ }^{77}$, de manera que será el juzgador el que caso por caso, determine tal característica de acuerdo a las circunstancias. En esta línea, la mera probabilidad no es suficiente, pero tampoco la alta probabilidad es la única posibilidad de considerarla como $\mathrm{tal}^{78}$.

La ley chilena se refiere a un criterio más bien objetivo a la hora de calificar tal circunstancia al emplear la expresión "que por su naturaleza sea capaz de influir" en la cotización de los valores emitidos. De este modo, debe existir una relación de causa-efecto entre el conocimiento que se tenga de tal información (causa) y la variación del precio (efecto), en términos tales que esta última resulte como consecuencia directa, inmediata y necesaria de dicho conocimiento, debiendo apreciar la aptitud o capacidad de influir en la cotización de un valor sobre la base de una realidad económica y no a partir de ejercicios o premisas abstractos y meramente teóricos, como podría ser la calificación de "hecho esencial" formulado por la propia entidad emisora de la información ${ }^{79}$.

La naturaleza de la información dice relación con la capacidad de esta para influir, lo que debe analizarse desde un punto de vista objetivo. En otras palabras, las circunstancias deben referirse a la información misma y su aptitud para tales efectos, tomando en consideración criterios objetivos y no factores exógenos o subjetivos de terceras personas, ni por estar contenida en cierta clase de instrumento. Tal examen requiere evaluar y ponderar todas las circunstancias externas, bajo un análisis basado en la realidad de los hechos, ajena e independiente de la especulación financiera y de los ejercicios teóricos, con el objeto de determinar en concreto cómo concurren en la hipótesis sometida al conocimiento del tribunal ${ }^{80}$.

76 Entrena Ruiz (2006) 67-70.

77 Sánchez-Calero Guilarte, Fernando (1987). "En torno al concepto de información privilegiada (insiders Trading y operaciones de iniciado)", Revista de Derecho Bancario y Bursátil.

78 Para Gómez Iniesta (1997) 128. la oscilación en un precio debe ser tal que sobrepase la medida de lo que viene a ser habitual en el mercado, lo que únicamente podría ser determinado por un perito en la materia.

79 Véase: Sentencia dictada por al SVS en causa "Silva, Francisco con SVS", 1997.

$80 \quad$ En tal sentido AlCalde Rodríguez (2000), Raúl Varela señala sobre el particular que: “...En síntesis, este proceso de análisis de la relación de causalidad que debe existir en esta materia exige que el juez realice un ejercicio intelectual consistente, primero, en determinar si el hecho de contar con determinada información confidencial es en sí mismo y objetivamente capaz de influir en la cotización (es decir, causa adecuada de tal resultado), para luego una vez establecido lo anterior, examinar si a la luz de los antecedentes particulares del caso es posible concluir que de haberse divulgado la información dicha cotización hubiere variado. Solo en 
En este ejercicio será pertinente establecer parámetros generales en cuanto a la necesidad que exista una relación de causalidad entre la información y el cambio que pueda presentar la cotización de determinado valor, con lo cual se dejan fuera una serie de datos o hechos. En tal sentido, por ejemplo, la clave de la caja de fondo de un banco es un dato que merece ser guardado en secreto, sin embargo por el hecho que el gerente de dicho banco la revele, ello no desencadenaría el efecto que el legislador buscó evitar, como es afectar la cotización de los valores, es más, dicha información no puede considerarse como privilegiada ya que no genera alzas ni disminuciones en la cotización de los valores emitidos; ni influye en la cotización de los valores como exige el Artículo 164 de la Ley de Mercado de Valores ${ }^{81}$.

La información debe ser relevante por su propia naturaleza y no por circunstancias externas o subjetivas, de lo contrario no existiría la posibilidad de prever con certeza la ilicitud de dicha actuación.

En relación a la cuestión de si el sujeto debe prever las consecuencias del uso de información por él practicado, hemos de considerar que el legislador nada señala al respecto, de manera que no es un requerimiento que pueda exigirse para configurar la conducta. Basta que él sepa que la información ostenta el carácter de privilegiada (no pública), que se encuentre en algunos de los supuestos a que alude el Art. 165 y 166 de la LMV, incumpla algunas de las obligaciones que este último precepto describe, y que ello provoque los efectos descritos en el Art. 164, esto es, este hecho influya en la cotización de los valores emitidos, para que esta conducta se enmarque en el supuesto descrito y sea sancionada. Para determinar si una información es objetivamente relevante para el sujeto que la utiliza, que es a quien en definitiva se sanciona, normalmente se recurre al parámetro de hombre medio, razonable o prudente, pero entendido en el contexto del individuo que se desenvuelve y opera en el mercado de valores $^{82}$.

Sobre el particular, la causa más relevante que puede analizarse es el caso LAN. Los hechos son los siguientes: en la mañana del 24 de julio de 2006 el Directorio de LAN Airlines SA acordó repartir un dividendo provisorio de USD 0,15071 por acción y aprobó la FECU de la Sociedad al 30.06.2006. Durante la tarde de ese mismo día, la sociedad Inversiones Santa Cecilia S.A., representada por el señor Piñera y Cantábrico SA, representada por el Sr. Cueto, compraron sendos paquetes de acciones LAN al precio de $\$ 3.280$ cada una (250.000 acciones). Al día siguiente,

el evento de que la respuesta a ambas cuestiones sea afirmativa podrá entonces considerarse que el conocimiento de la respectiva información confidencial ha influido en el valor del título y, por ende, está calificada como información privilegiada”. VARELA Morgan

81 Véase: Varela Morgan

82 Teniendo como referencia el Art. 90 de la LMV en la calificación de "información esencial". 
cuando el mercado ya estaba cerrado, la Sociedad informó la aprobación de la FECU a la Superintendencia y al mercado en general. La conducta precedentemente descrita fue sancionada por la SVS, por considerar que se había quebrantado el deber de abstención estipulado en el Art. 165 LMV.

En este caso lo que se cuestionó fue precisamente si la FECU tenía el carácter de información privilegiada ${ }^{83}$. Finalmente la CA de Santiago desestimó los recursos interpuestos por el reclamante ${ }^{84}$, confirmando la sentencia de primera instancia con fecha 8 de marzo de 2010, incluyendo la parte que estima que los estados financiero constituyen información privilegiada "per se", atendiendo a los argumentos esgrimidos por la SVS.

Ciertamente, esta causa pone en jaque los elementos configuradores de la información privilegiada, especialmente, la relevancia y su trascendencia, en tanto la FECU debe informarse y como tal, se entiende que la información allí contenida es esencial de acuerdo a la normativa vigente. Si reviste este último carácter, entonces, su conocimiento puede provocar variaciones en la cotización de los valores ligados a ella, empero, el asunto es que efectivamente si la información era conocida por los operadores del mercado, ello no acontecerá. La pregunta es, ¿¿deben reunirse necesariamente ambos caracteres de manera conjunta? Los tribunales resuelven bien este dilema, aplicando para ello la ley de manera estricta. En tal sentido, argumentan, que no se requiere acreditar la influencia, sino solo tener la certeza que ello podría haber ocurrido. Pues bien, a nuestro juicio, lo que faltó en este razonamiento fue evidenciar que la información en cuestión "por su propia naturaleza" tenía este carácter, al tratarse de una información esencial que debía publicitarse en breve plazo. Antes de que se aprobara la FECU, existían "rumores" o simples datos sobre hechos, no una información propiamente tal, de manera que las distinciones antes esbozadas aquí cobran pleno sentido.

\section{(3.3.5) Cuadro comparativo sobre los elementos que se exigen para configurar la noción de información privilegiada}

Nos parece relevante, a los efectos de comprender la envergadura del análisis efectuado precedentemente, comparar el contenido de nuestra legislación, específicamente en lo que respecta al Art. 164, con la noción normativa que a estos efectos se ha construido en Derecho comparado.

83 Sobre este caso, en detalle Véase: VÁsquez Palma, Ma. Fernanda (2010). "Caso LAN y uso de información privilegiada: Un análisis de la correcta delimitación de las infracciones legales", Ius et Praxis, No2 (En Prensa).

84 El reclamante era Juan José Cueto Plaza. A pesar de que Sebastián Piñera también había sido sancionado por los mismos hechos y causal, él pagó la multa y no prosiguió la reclamación judicial. 
En función de su relevancia, decidimos efectuar tal análisis con la Directiva Europea sobre abuso de mercado ${ }^{85}$, con el objeto de detectar sus mayores diferencias y similitudes.

Elementos

Tipo y carácter

Publicidad

Carácter de la información

\section{Art. 164 LMV Chile}

a. Cualquier información que cumpla los requisitos señalados en el inc $1^{\circ}$ del Art. 164.

b. Información reservada. c. La que se posee sobre decisiones de adquisición, enajenación y aceptación o rechazo de ofertas específicas de un inversionista institucional en el MV.

No divulgada al mercado.

No hay referencia a su carácter concreto.

\section{Elementos de la noción de la información privilegiada en el Art. $1^{\circ}$ de la Directiva Europea.}

No hay distintos tipos de información. Se realiza una distinción relativa a la información; instrumentos; y personas encargadas de la ejecución de las órdenes relativas a instrumentos financieros.

Que no se haya hecho pública.

Se requiere un carácter concreto.

85 Directiva sobre insiders trading 2003/6/CE del Parlamento europeo y del Consejo de 28 de enero de 2003, sobre las "Operaciones con información privilegiada y la manipulación del mercado", modificada por la Directiva 2008/26/CE, de 11 de marzo de 2008, en lo que concierne a competencias de ejecución de la Comisión. En lo medular el Art. 10 dispone: “ $A$ efectos de la presente Directiva, se entenderá por 1) información privilegiada: la información de carácter concreto, que no se haya hecho pública, y que se refiere directa o indirectamente a uno $o$ varios emisores de instrumentos financieros o a uno o varios instrumentos financieros, y que, de hacerse pública, podría influir de manera apreciable sobre la cotización de esos instrumentos financieros o sobre la cotización de instrumentos financieros derivados relacionados con ellos. En relación con los instrumentos derivados sobre materias primas, información privilegiada significará la información, de carácter concreto, que no se haya hecho pública, y que se refiera directa $o$ indirectamente a uno o varios de esos instrumentos derivados, que los usuarios de los mercados en que se negocien esos productos esperarian recibir con arreglo a las prácticas de mercado aceptadas en dichos mercados. En cuanto a las personas encargadas de la ejecución de las órdenes relativas a los instrumentos financieros, también se considerará información privilegiada toda información transmitida por un cliente en relación con sus propias órdenes pendientes, que sea de carácter concreto, y que se refiera directa o indirectamente a uno o varios emisores de instrumentos financieros o a uno o varios instrumentos financieros y que, de hacerse pública, podría tener repercusiones significativas en los precios de dichos instrumentos financieros o en los precios de los instrumentos financieros derivados relacionados con ellos". 
Ámbito de aplicación objetivo o material.

Trascendencia.
La general: Referida a uno o varios emisores de valores, a sus negocios o a uno o varios valores por ellos emitidos.
Que se refiera directamente a uno o varios emisores de instrumentos financieros o a uno o varios instrumentos financieros-Negociados o pendientes de admisión o negociación en un mercado regulado europeo, con independencia de que la operación o quien la efectúa desarrollen fuera del mismo.

Que de hacerse pública podría influir de manera apreciable sobre la cotización de esos instrumentos financieros o sobre la cotización de esos instrumentos financieros o sobre la cotización de los instrumentos financieros derivados relacionados con ellos.

\section{3) ÁMBITO DE APLICACIÓN SUBJETIVO Y CONDUCTAS PROHIBIDAS}

\section{1) BREVE ANÁLISIS DE LA NORMATIVA QUE RIGE LA MATERIA}

El Art. 165 de la LMV ${ }^{86}$ se ocupa de discernir principalmente cuáles son los sujetos que están involucrados en esta prohibición y las conductas

$86 \quad$ El artículo 165 de la LMV, prescribe: "Cualquier persona que en razón de su cargo, posición, actividad o relación con el respectivo emisor de valores o con las personas señaladas en el artículo siguiente, posea información privilegiada, deberá guardar reserva y no podrá utilizarla en beneficio propio o ajeno, ni adquirir o enajenar, para si o para terceros, directamente o a través de otras personas los valores sobre los cuales posea información privilegiada.

Asimismo, se les prohibe valerse de la información privilegiada para obtener beneficios o evitar pérdidas, mediante cualquier tipo de operación con los valores a que ella se refiera o con instrumentos cuya rentabilidad esté determinada por esos valores. Igualmente, se abstendrán de comunicar dicha información a terceros o de recomendar la adquisición o enajenación de los valores citados, velando para que esto tampoco ocurra a través de subordinados o terceros de su confianza. No obstante lo dispuesto precedentemente, los intermediarios de valores que posean la información privilegiada a que se refiere el articulo anterior, podrán hacer operaciones respecto de los valores a que ella se refiere, por cuenta de terceros, no relacionados a ellos, siempre que la orden y las condiciones específicas de la operación provenga del cliente, sin asesoría ni recomendación del intermediario, y la operación se ajuste a su norma interna, establecida de conformidad al artículo 33. Para los efectos del inciso segundo de este articulo, las transacciones se entenderán realizadas en la fecha en que se efectúe la adquisición o enajenación, con independencia de la fecha en que se registren en el emisor". 
castigadas; no obstante, de la sola lectura de esta disposición se puede apreciar cierta confusión y repetición innecesaria que abren algunas interrogantes sobre los objetivos legislativos que se tuvieron en mente en el proceso de la creación y redacción de la norma en cuestión. El legislador no usó una técnica jurídica depurada de modo de describir claramente los sujetos responsables y las conductas reprochables, por ejemplo, la norma es confusa y redundante al emplear la expresión "asimismo" como si se tratase de cuestiones diversas, cuando en realidad lo que parece hacer el inciso segundo es explicar el contexto en que tal utilización podría producirse, lo que puede desprenderse de la frase: "mediante cualquier tipo de operación con los valores a que ella se refiera o con instrumentos cuya rentabilidad esté determinada por esos valores".

Debido a lo anterior, este ámbito se logra descifrar solo después de un proceso de interpretación sistemático de la Ley ${ }^{87}$, pero que de ninguna manera plantea una comprensión unánime para los autores y la doctrina jurisprudencial.

\section{2) Sujeto ACTIVO DE LA CONDUCTA}

\section{(3.2.1) Delimitación subjetiva del mandato legal}

De la disposición antes transcrita se desprende que el uso de información privilegiada es, por regla general, lícito. Será ilícito solo cuando ciertas personas que en razón de su cargo, posición, actividad o relación con el emisor de valores o con las personas señaladas en el Art. 166 posean información privilegiada e incumplan el mandato y prohibiciones legales aquí expresadas ${ }^{88}$. Esta prohibición se les aplica aun cuando cesen en el ejercicio de estas funciones (Art. 167). El inciso tercero de la citada disposición plantea que también están vinculados al mandato legal los intermediarios de valores, de manera que ordena, a los que posean información privilegiada, hacer operaciones solo por cuenta de terceros no relacionados a ellos, siempre que la orden y las condiciones específicas de la operación provenga del cliente, sin asesoría ni recomendación del

Véase: Varela Morgan.

El derogado Art. 13 de la LMV atribuía el tema de la utilización abusiva solo en un contexto referido al Derecho societario y se refería como sujetos de estas conductas a "Los directores, administradores y, en general, cualquier persona que en razón de su cargo o posición tenga acceso a información de la sociedad". A su vez, el único objeto era la compra o venta de acciones emitidos por esta. La regulación posterior amplía el ámbito de los sujetos obligados con el deber de reserva, extendiendo la categoría de los iniciados a "cualquier persona que en razón de su cargo, posición, actividad o relación, tenga acceso a información privilegiada", de la que "deberá guardar estricta reserva y no podrá utilizarla en beneficio propio o ajeno, ni adquirir para sí o para terceros, directa o indirectamente, los valores sobre los cuales posea información privilegiada" (Art. 164). 
intermediario, y la operación se ajuste a su norma interna, establecida de conformidad al artículo 33.

Debido a la amplitud descrita el ámbito de aplicación subjetivo principalmente en su primera parte, este debe ser examinado e interpretado a partir de los límites que impone el principio de legalidad. En tal sentido debemos atender necesariamente a tres requisitos: a. El sujeto debe encontrarse en un presupuesto determinado que se especifica como: cargo, posición, actividad o relación. b. Este debe estar en conexión con el emisor de valores o alguna de las personas señaladas en el Art. 166 de la LMV. y c. El sujeto debe poseer información privilegiada derivado de dichas situaciones, de manera que se exige una relación previa con el sujeto del que emana la fuente de la información ${ }^{89}$, lo que se aprecia del factor de conexión derivado de la frase "en razón de" utilizada por el legislador. En otras palabras, debemos distinguir entre un sujeto activo, que llega a poseer la información a partir de determinados hechos o circunstancias, del sujeto pasivo, del cual emana la información (primera o segunda fuente), entre ambos debe existir una relación directa y consecuencial ${ }^{90}$.

Estos requisitos son copulativos de modo que el legislador exige que la posesión de la información sea precedida de una cierta posición y la existencia de un vaso comunicante entre esta y alguna de las conexiones antes descritas. Si el sujeto posee la información por noticias de un tercero (no señalado en la norma) u de otros caminos diversos a los relatados, este no podría ser considerado como sujeto activo de esta conducta, distinto es si esta información tenía derecho a conocerla en base a su especial cargo, función o actividad, o se encontraba disponible para este, pues en este caso la conducta será sancionada independiente del canal de información.

Como se puede apreciar, la hipótesis general descrita por el legislador reside en la afirmación que el potencial responsable de la infracción que nos ocupa es un sujeto con posibilidades de poseer la información en razón de su profesión, cargo, actividad o relación, de manera que para

89 Véase: Oficio Circular No 2.506 de 10 de julio de 1997, de la SVS, en el cual se precisan estos conceptos sistematizados por la ley 19.301 .

90 La Directiva Europea 2003/6/CE dispone sobre este punto que: 1. Los Estados miembros prohibirán a cualquier persona de las citadas en el párrafo segundo que posea información privilegiada utilizar dicha información adquiriendo o cediendo o intentando adquirir o ceder, por cuenta propia o de terceros, directa o indirectamente, instrumentos financieros a que se refiera dicha información. El primer párrafo se aplicará a cualquier persona que esté en posesión de esa información: a) por su condición de miembro de los órganos de administración, gestión o control del emisor; b) por su participación en el capital del emisor; c) por tener acceso a dicha información debido al ejercicio de su trabajo, de su profesión o de sus funciones, o d) debido a sus actividades delictivas. 2. Cuando las personas a las que se refiere el apartado 1 sean personas jurídicas, la prohibición expresada en dicho apartado se aplicará también a las personas físicas que hubieren participado en la decisión de proceder a la operación por cuenta de la persona jurídica en cuestión (...)”. 
comprender el real alcance de esta disposición, debemos despejar necesariamente el significado de los vocablos "cargo, profesión, actividad y relación". Sobre el particular habría que entender que el "cargo" se aplica a las personas que intervienen como ejecutivos del propio emisor (por ejemplo, un director o un gerente de una sociedad anónima). La "posición" se emplea respecto de aquel que sin ocupar un cargo actúa permanente o esporádicamente frente a la compañía como fuente de información, por ejemplo, un auditor externo. La "actividad" se refiere a operaciones o tareas que una persona desarrolla o desempeña en una empresa, y por "relación" debe entenderse a cualquier otro vínculo, enlace o trato que vincule al sujeto con la fuente ${ }^{91}$.

Se aprecia que estas nociones están desprovistas de una interpretación restrictiva, de manera que no podemos realizar un listado taxativo de las mismas. En estos supuestos comprender un enorme listado de personas que simplemente trabajan o se relacionan con el emisor aun cuando no lo hagan en base a su profesión (quedarían aquí admitidos, por ejemplo, el ascensorista y el novio de la secretaria), debido a esto, al momento de su interpretación podrán presentarse dudas sobre el exacto encuadramiento de algunos sujetos en el ámbito de aplicación descrito. En estos casos se debería evaluar si existe formalmente o de facto el desempeño de funciones de dirección o control, o si ha operado alguno de los factores de conexión descritos anteriormente en la obtención de la información. Ciertamente, establecer este listado sería más sencillo si los emisores de valores llevaran un registro documental en que consten los nombres de las personas que accedan a la información de la sociedad y la fecha en que cada una ha conocido la información, pero en Chile, tal situación es completamente voluntaria, lo que vuelve compleja la operación de discernir este catálogo 92 .

La expresión normativa "cualquier persona" hace referencia tanto a una persona natural como jurídica si se sitúa en algunos de los supuestos antes mencionados, principalmente el referido a las conexiones por actividad y relación (Ej. Posible fusión, anuncio de una OPA, etc.). En esta materia, resulta ilustrativo el fallo pronunciado en la causa "Hurtado Vicuña, Juan y otros c/Superintendencia de Valores y Seguros", pronunciado por la CS con fecha 27 de octubre de 2005, que aclara justamente este punto en la dirección propuesta ${ }^{93}$.

Prado Puga (2003) 263.

En esta línea, la doctrina pareciera estar conteste en el hecho que debe existir cierta subordinación al órgano de administración, o bien sin tener relación laboral, ejerciten poderes sobre el emisor. Entrena Ruiz (2006) 202 y ss.

93 Este fallo señala en lo medular: "Que, dada la amplitud de la norma recién mencionada, su ámbito de aplicación es extenso y comprende a todas las personas que en razón de su cargo, posición, actividad o relación tengan acceso a información de carácter privilegiada; y al decir "cualquier persona" se involucra tanto a las personas naturales como a las jurídicas, pues 


\section{(3.2.2) Fundamento del sujeto activo de la conducta}

Otro de los debates doctrinales que ha despertado la determinación del ámbito de aplicación subjetivo de este mandato se refiere a si es posible considerar como sujeto infractor al que genera o contribuye a la generación de la información. Para un sector aquel no estaría comprendido en dicha articulación, esgrimiéndose al efecto que ello no se sustentaría en ninguna situación de privilegio en el sentido que exige la figura analizada, pues no puede entenderse que ha tenido acceso a la misma cuando ha sido precisamente ella quien la origina. Para esta tesis, habría que considerar que el Art. 165 parte de la hipótesis que la persona posee esta información en razón de su cargo, posición, actividad o relación y nada se dice respecto de quien ha intervenido en la transacción o acto jurídico que origina la información, si así fuese, se llegaría al absurdo que tal sujeto no podría participar en el mercado pues estaría obligado a no adquirir las acciones, con lo que la información privilegiada no llegaría a nacer ${ }^{94}$.

El asunto no es baladí en tanto liga con la problemática de a quién le pertenece validamente la información ${ }^{95}$ y el reconocimiento que esta puede generarse por terceros distintos al emisor ${ }^{96}$. Al mismo tiempo, de considerar que el emisor no puede tener la calidad de iniciado al tratarse de una persona jurídica que debe actuar representada, correspondería determinar si puede ser responsable y desde qué óptica ${ }^{97}$. Adicionalmente, este asunto se vincula con la determinación de los fundamentos de la ley.

Este último de los puntos es, a nuestro juicio, el más relevante, en tanto esta inquietud pone en jaque justamente los principios que subyacen a la delimitación del sujeto activo de la conducta. Frente a ello cabe tener presente que han sido distintos argumentos los que han fundado este ilícito y consiguiente responsabilidad en Derecho comparado. Así,

el legislador no distinguió entre unas u otras. La norma en comento comprende la prohibición total de adquisición o venta para sí o para terceros de los valores respecto de los cuales se posea información privilegiada, y su incumplimiento trae como consecuencia la imposición de la sanción contemplada en la ley".

94 Bajo esta lógica, la persona que a través de una actuación suya, lícita y ajustada a la ley, genera o cogenera información, se hace dueña de la misma, pudiendo, por tanto, usar, gozar y disponer de ella, de manera tal que si un determinado sujeto se encuentra negociando con otro la adquisición de un paquete importante de acciones con miras a adquirir el control de una sociedad y, en forma previa al perfeccionamiento del contrato que le permitirá adquirir dicho porcentaje, o bien antes que tal contrato sea conocido del mercado, compra acciones a otros accionistas diversos, no cabría considerar que ha hecho uso de información privilegiada. Sobre el particular, Alcalde Rodríguez (2000) 16; Guzmán Anrique (2009) 77-80.

95 Véase: Salah Abusleme (2005) 3-6; Guzmán Anrique (2009) 128-137; Alcalde Silva, Jaime (2010). "La extensión temporal del deber de secreto de los administradores sociales", Revista de Derecho Mercantil No 275, pp. 11-14.

96 Bolsa (2007). "Información generada por terceros distintos del emisor", Revista Mensual de Bolsas y Mercados Españoles, No 168, pp. 41-53.

97 Entrena Ruiz (2006) 277-351. 
en el Derecho norteamericano se han ensayado básicamente tres teorías ${ }^{98}$ : the equal access theory (teoría del acceso igualitario); the fiduciary duty theory (teoría del deber de confianza) y the misapprpriation theory (teoría de la apropiación indebida ${ }^{99}$, como es lógico, la adopción de una de ellas provoca particulares consecuencias en esta delimitación infraccional ${ }^{100}$. En Chile se han esgrimido los principios de "simetría y transparencia de la información” como fundamentos de la ley, de manera que de acuerdo a esta lógica se podría incluir incluso al generador de esta información en pos del resguardo de dichos principios. Esta es la tesis que hasta el momento ha seguido nuestra jurisprudencia ${ }^{101}$.

98 Si bien la dirección dada por su normativa se orienta al deber fiduciario que nace a partir de una relación orgánica para castigar el uso de información privilegiada, no es menos cierto que se ha discutido muchas veces la posibilidad de extender este campo de aplicación, principalmente a partir de la interpretación de la norma transcrita (10b) que plantea un enunciado amplio al aludir a cualquier persona. Ha sido a partir del trabajo jurisprudencial que se ha podido depurar con mayor nitidez este ámbito de aplicación subjetivo. Por este camino, la evolución ha sido marcada desde la instauración de esta normativa, comenzando por sancionar a la persona de alto cargo del deber fiduciario y lealtad para con los accionistas (director o ejecutivo), pasando por aquella verificada en forma indirecta, cuando la información concreta y no pública es comunicada aun tercero o tippe que la vulnera. En las últimas décadas se ha desprendido del factor subjetivo, aludiendo solo a la fuente de donde emerge la información (missapropiation theory), de manera tal que los criterios empleados son la teoría del fraude y la apropiación indebida. De esta forma, lo que se castiga es el deber de lealtad que el ousiders tiene, no ya con los accionistas, sino con su fuente de información originaria. Véase: http://www.law.unlv.edu/faculty/rlawless/mergers/ohagan.htm (2/7/03)

99 Sobre el particular, Véase: López BarJa de Quiroga (1998) 343-345.

100 Véase: casos de EEUU: Carpenter (1986) y O`Hagan (1997).

101 Sobre el particular, uno de los pocos fallos que se ha pronunciado sobre esta materia es la causa "Elesur S.A. c/ Superintendencia de Valores y Seguros", ya comentado, por la Corte Suprema con fecha 26 de julio de 2007, que sentenció: “...Que, como se puede advertir, el legislador al referirse a "cualquier persona" no hizo distingo alguno entre las que tuvieron participación en la génesis de la información y las que no, y ello es totalmente coherente con el espíritu de la ley en comento, que pretende proteger el orden público económico a través de la igualdad de la información que debe existir entre los operadores del mercado. Carece de toda lógica lo aseverado por el recurrente, en cuanto a que para estar frente a información privilegiada se requiere necesariamente que quien la obtenga sea un tercero, desde que lo que se protege con nuestra normativa legal no es el derecho a la información, sino el derecho de los distintos operadores a intervenir en el mercado de valores teniendo un acceso igualitario a la información en base a la cual adoptan sus decisiones, para así estar frente a un mercado transparente, y evitar el plano de desventaja en que puede encontrarse quien desconoce información relevante para adoptar la decisión, por no haber tenido la posibilidad de acceder a ella, en relación a quien si la conoce en relación a su cargo, posición, actividad o relación(...)”. La sentencia del 10 Juzgado Civil de Santiago, Causa Rol No C-4.393.97, "Elesur SA. V. SVS", había entendió lo contrario en la materia, al expresar: "Para infringir la norma, la información debe ser objeto de apropiación indebida, lo que por cierto conlleva a la vulneración de igualdad de oportunidades que ha manifestado la demandada (SVS) habría existido en el caso de autos y que, en concepto de este tribunal, no ha sido tal (...)Que de ocurrir lo seńalado de una manera diversa a aquella expresada en el motivo precedente, se presentaría el absurdo de paralizar cualquier iniciativa en el mercado de valores, toda vez que, al crear un movimiento de valores, llamando a una OPA, se temería desde luego la sanción administrativa, o incluso penal, cosa que no pudo haber estado en 
Con todo, tal apreciación es perfectamente cuestionable en tanto no se condicen con la norma en estudio, prueba de ello es que no se sanciona "a toda persona", sino solo a ciertos sujetos que se encuentran en una especial posición de la cual les es posible poseer cierta información, lo que nos obliga a sostener que el fundamento debe verse desde una óptica más restringida que sirva para explicar y fundamentar por qué se sanciona a estos sujetos y no a otros. Frente a ello y a pesar de la falta de claridad expositiva, necesariamente llegaremos a la conclusión que el legislador parte de un "deber de fidelidad" como fundamento de su delimitación, pues no sanciona todo uso de información, sino solo aquel que nace como consecuencia de una determinada posición. Adicionalmente, una interpretación estricta del Art. 165 necesariamente debe descartar la posibilidad que se sancione al emisor o dueño de la información propiamente tal, al no estar contemplada esta posibilidad en la norma en cuestión.

\section{(3.2.3) Presunciones de posesión de información privilegiada}

Estas presunciones se establecen en el Art. 166 de la LMV ${ }^{102}$. Se aprecia en la primera parte de esta disposición una referencia directa a los insiders de quienes presume la posesión de información privilegiada en tanto usuarios primarios, en base a su especial labor o cargo desempeńado con la fuente de información. En la segunda parte, la situación cambia en tanto no existe un vínculo directo con la fuente, sino con el objeto

el espíritu de la ley, máxime si de los antecedentes acompańados no se ha sufrido perjuicio para terceros (...)".

102 El Art. 166 de la LMV prescribe que: "Se presume que poseen información privilegiada las siguientes personas: a) Los directores, gerentes, administradores, ejecutivos principales y liquidadores del emisor o del inversionista institucional, en su caso. b) Las personas indicadas en la letra a) precedente, que se desempeñen en el controlador del emisor o del inversionista institucional, en su caso. c) Las personas controladoras o sus representantes, que realicen operaciones o negociaciones tendientes a la enajenación del control. d) Los directores, gerentes, administradores, apoderados, ejecutivos principales, asesores financieros u operadores de intermediarios de valores, respecto de la información del inciso segundo del artículo 164 y de aquella relativa a la colocación de valores que les hubiere sido encomendada.

También se presume que poseen información privilegiada, en la medida que tuvieron acceso directo al hecho objeto de la información, las siguientes personas: a) Los ejecutivos principales y dependientes de las empresas de auditoría externa del emisor o del inversionista institucional, en su caso b) Los socios, gerentes administradores y ejecutivos principales y miembros de los consejos de clasificación de las sociedades clasificadoras de riesgo, que clasifiquen valores del emisor o a este último. c) Los dependientes que trabajen bajo la dirección o supervisión directa de los directores, gerentes, administradores, ejecutivos principales o liquidadores del emisor o del inversionista institucional, en su caso. d) Las personas que presten servicios de asesorias permanente o temporal al emisor o inversionista institucional, en su caso, en la medida que la naturaleza de sus servicios les pueda permitir acceso a dicha información. e) Los funcionarios públicos dependientes de las instituciones que fiscalicen a emisores de valores de oferta pública o a fondos autorizados por ley. f) Los cónyuges o convivientes de las personas señaladas en la letra a) del inciso primero, así como cualquier persona que habite en su mismo domicilio". 
de la información para conformar la presunción, de manera tal que para demostrar la posesión de los primeros bastará con acreditar su calidad, cargo, o trabajo; mientras que en los segundos se deberá probar que las personas allí señaladas tuvieron acceso directo al hecho objeto de la información, lo que cambia diametralmente la aplicación de la presunción en comento, pues solo en la medida que se acredite este supuesto se les podría aplicar esta presunción ${ }^{103}$.

En este elenco se otorga una predominancia al carácter de la relación existente entre la fuente de la información y la existencia de una relación determinada, principalmente nacidas o vinculadas a cargos de confianza de tipo laboral o de desempeño de labores en el funcionamiento de una empresa y/o del mercado de valores en general. La única excepción la constituye la presunción relativa al cónyuge o conviviente de alguna de las personas señaladas en la letra a) del inciso primero, ya que parte del supuesto que estos tienen acceso a dicha información solo sobre la base de una relación de carácter personal, de manera que no se basa en verdad en la lógica antes relatada.

La finalidad de establecer este elenco se centra claramente en un intento por delimitar a los posibles sujetos infractores del mandato legal de uso de información privilegiada, facilitando de paso la prueba de la posesión de la información o de su acceso. En todo caso, se trata de una presunción simplemente legal que puede ser desvirtuada.

\section{(3.2.4) Extensión del ámbito de aplicación a terceros: vis expansiva}

Como vimos, de acuerdo al Art. 165 LMV el deber recae en el sujeto que por su "cargo, posición, actividad o relación con el emisor o con las personas señaladas en el Art. 166 posee información privilegiada"104. A partir de ello se han formulado distinciones entre insiders y outsiders. Los primeros se subdividen, a su vez, en insiders primarios, que son aquellas personas que por su posición en el órgano emisor, sea como administrador, partícipe del capital social, trabajo, profesión o función, tienen acceso a información privilegiada ${ }^{105}$, y los insiders secundarios (tippess)

103 Es por ello que Sandoval ha señalado que este segundo grupo de presunciones no tendría, en realidad, una aplicación práctica, pues habrá de probar el acceso a la información. SANDoval López, Ricardo (2005). Derecho comercial. Sociedades de personal y capital, Santiago: Ed. Jurídica de Chile, 6a edición, Tomo I, pp. 198-199.

104 El único sujeto distinto de aquellos al que se dirige un deber específico, es al intermediario de valores al restringir sus posibilidades para utilizar la información en sus operaciones en el inciso tercero del Art. 165 LMV.

105 Se distinguen en este grupo a los corporate insiders, que tienen un rol fundamental en la administración societaria (directores ejecutivos, accionistas con una lato porcentaje accionario); los temporary insiders, que son aquellos que entran en una especial relación de confianza con la sociedad para gestionar asuntos de esta, permitiéndoles acceso a información privi- 
que son aquellos que han recibido una información de un insiders primario (tipping) ${ }^{106}$. En principio la regulación solo se dirige a los primeros, para que los segundos sean sancionados, estos debieran poseer un deber de fidelidad con el insiders o con el emisor, y conocer (o deber saber) el carácter privilegiado de la información. Los outsiders, esto es, aquellos que no tienen estas relaciones, en principio, no son alcanzados por el mandato legal.

El problema que podemos advertir surge como consecuencia de la falta de precisión del fundamento que subyace a esta prohibición, en tanto en la terminología empleada por el legislador no se alude a ninguna fuente de confianza sino al desempeńo de un cargo, posición, actividad o relación, dejando con ello abierta la posibilidad de extender este ámbito de aplicación más allá de lo prudente (por ejemplo, con la delimitación de "actividad o relación"). Interesa, por tanto, determinar hasta qué punto una persona, que en principio puede parecer un simple tercero, puede ser alcanzado con este mandato legal, es otras palabras, corresponde desentrañar cuándo y bajo qué circunstancias nuestro legislador permite que un sujeto sea alcanzado por el uso de información privilegiada.

La norma en comento se refiere de manera particular a dos tipos de terceros: a. Aquellos que llegan a tener conocimiento de dicha información por haber sido confidenciada por el sujeto enunciado en la primera parte del Art. 165; y b) Terceros que obtienen esta información en calidad de subordinados o por la confianza del sujeto en referencia. Si analizamos la disposición visualizamos en estos casos existe una clara diferencia en relación a la conducta que debe asumir el sujeto infractor. En efecto, el tercero signado con la letra a se entiende desprendido de toda vinculación con el que le entrega la información, mientras que en el último caso existe un vínculo de subordinación o confianza, esto provoca que en el primer caso se exija una conducta activa o dolo de parte del sujeto descrito en el Art. 165, mientras que en el segundo, baste solo una conducta pasiva, sumado al incumplimiento de un deber de cuidado, esto es, culpa.

Lo relevante es que los terceros no son considerados como sujetos infractores de este deber, toda vez que no se les brinda una especial carga de comportamiento en relación a la información poseída. La imposición normativa siempre alude al comportamiento del sujeto descrito en el inciso primero, inclusive, lo sanciona por el hecho de comunicar la información a un tercero, aun cuando no fuera utilizada, mas nada señala sobre este último y si una vez que accede o posee la información presenta un especial deber de custodia respecto de ella, o una prohibición de uso de la

legiada relativa a la misma (contadores, abogados, auditores externos, etc.); los mandatarios, los funcionarios públicos, entre otros.

106 Sobre el tema, Véase: GuZMán AnriQue (2009) 32. 
misma ${ }^{107}$. Quizá ello se funda en el hecho que si la información ha sido comunicada a un tercero (que en realidad podrían ser varios), esta ha pasado a ser pública y ya no reviste por tanto el carácter de privilegiada, por lo que la sanción perdería sustento ${ }^{108}$.

La sanción el outsiders es polémica si se revisa desde su fundamentación, así, si se esgrime que esta radica en el deber de fidelidad con el ente emisor, estos no podrán ser alcanzados en ningún caso, pues no tienen tal deber, a menos que se asuma un deber de fidelidad derivado ${ }^{109}$; mientras que si fundamentamos su sanción en el resguardo del principio de igual-

107 Si observamos las normas sancionadoras, podríamos arribar a una solución un tanto más difusa. En efecto, el Art. 60 de la LMV sanciona con presidio menor en cualquiera de sus grados dos formas de conductas diversas. La primera está dirigida a los supuestos a que se refiere el Art. 166 y usen la información de la que disponen, el segundo se trata de infracciones al deber de reserva que presenta por medio del enunciado "El que", lo que ha generado variadas interpretaciones sobre su exacto encuadramiento. Sobre el particular, Véase: Piña Rochefort (2010) 122-125.

108 Se debe tener presente la tendencia existente en Derecho comparado, principalmente en EEUU. A modo de ejemplo: 1. Caso "Cady, Roberts \& Co", en que la SEC aplicando la teoría del fraude, elabora la doctrina del unfairness use, o la regla "revelar o abstenerse", frente al uso de información privilegiada concerniente al descubrimiento de un combustible desarrollado por la compañía Curtiss-Wright, sancionando a un agente de bolsa (broker) que vende acciones de dicha cía., utilizando una información que le había sido proporcionada antes de su divulgación por un Director social de una empresa (Corporate insiders), que accede a ella en razón de dicha posición de confianza. Los Tribunales sancionan tanto al Director que comunica la información como al agente (outsiders) que la emplea, obteniendo ventaja de la venta de acciones que habían disminuido de valor, entendiendo que la obligación de revelar cubre tanto las transacciones realizadas en la bolsa como fuera de ella. 2. Caso Shapiro/Meril Lynch Fenner \& Smith, en que se incorporan como terceros responsables a los receptores de la información, no existiendo un vínculo obligacional, sino solo con la información. La Corte acoge una demanda indemnizatoria colectiva de unos inversionistas sancionando en forma drástica y aplicando la regla de "revelar o abstenerse" a los informados por el solo hecho de acceder por vía indirecta a la información privilegiada. 3. Caso Chiarella v/s United States. Este fallo delimita la extensión de los sujetos obligados por la regla "revelar o abstenerse". En el caso, se pretende sancionar a un extrańo que accede a información, no en razón de una posición o función en una empresa, sino en virtud de un encargo laboral que el permita obtenerla. 4. En el Caso Dirks v/s SEC, se aborda la aplicación normativa a una persona completamente extraña a la empresa de donde emana la información, pretendiendo aplicar la teoría de "Participación después de los hechos" atribuyéndole la misma responsabilidad que a un insiders a un outsiders, ajeno a toda relación fiduciaria o deber de lealtad. 5. Caso United States v/s Carpenter, que afectó a un reportero del diario Wall Street Journal el que escribía una influyente columna sobre valores. El fraude consistió en haberse concertado para que los dos empleados de la firma accedieran a información sobre acciones, antes de que ella saliera publicada en la columna, avance que permitió a estos empleados de la corredora vender o adquirir valores por anticipado. Se condenó a los acusados por fraude, confirmando el uso indebido de la información, la que, no obstante, no ser suministrada por un emisor de valores, sino por un periodista de un diario, sosteniendo que este había quebrantado su deber de confidencialidad basado en su relación laboral, apropiándose de la información confidencial antes de ser publicada. 6. Caso United States v/s O'Hagan. Entre otros casos.

109 Véase: López BARJa de Quiroga, Jacobo (1998). El abuso de información privilegiada, en Bacigalupo, E. (Ed.): Curso de Derecho Penal Económico, Madrid: Marcial Pons, p. 342. 
dad en el acceso y uso de la información en el mercado de valores, entonces llegamos a una conclusión contraria debiendo sancionarse al outsiders al igual que el insiders.

Sobre este punto, parte de la doctrina ha planteado la necesidad de diferenciar si el tercero a quien se le proporciona la información sabía o debía saber que la información era confidencial y, por tanto, que llegó a su conocimiento por vía de infracción de ley, de aquellos que no podían prever tales circunstancias. Se extendería el ámbito de aplicación solo al primer caso sobre la base del principio que impide obtener beneficios de dolo ajeno, aun cuando hacemos presente que, en tal caso, su responsabilidad únicamente diría relación en el ámbito civil, con la consiguiente indemnización de perjuicios ${ }^{110}$.

En base a lo anterior, nos parece del todo relevante que en el futuro se distinga el comportamiento que el tercera adopte respecto de la información a que acceda o posea. No puede ser lo mismo que la información le sea entregada por un sujeto, sin mediar intención alguna de su parte, y este no realice ninguna operación con ella; de aquel tercero que, bajo el manto de subordinación y confianza que lo liga al sujeto poseedor de la información, accede a la información por su cuenta y luego la utiliza. En otras palabras, se presentan como puntos importantes a dilucidar no solo el conocimiento que el sujeto pueda tener sobre el tipo de información, sino además cómo accede (en qué calidad) y qué decide hacer con ella. Igualmente podríamos considerar la existencia de un deber de lealtad también por parte del tercero en base a la relación fiduciaria preexistente que lo vincula con la fuente de la información obtenida y la manera en que ésta ha sido empleada ${ }^{111}$. En todo caso, estimamos que nunca podría extenderse este manto de responsabilidad tratándose de informados remotos, que reciben casualmente o accidentalmente la información, como ocurriría con un taxista o un lego en temas financieros, conducta que exigiría una interpretación muy amplia que carece de justificación.

\section{3) CONDUCTA SANCIONADA}

No se sanciona -ni podría hacerse- la posesión de la información, sino su utilización en los términos descritos en el Art. 165. En relación a ello, lo primero que ha de indicarse es que en la configuración de la con-

110 Alcalde Rodríguez (2000) 16-17.

111 El criterio en estos casos podría ser derivativo (participant alter the fact), o bien, a través de un deber fiduciario (fiduciary duty), de manera de afectar y hacer responsables a individuos que están en posesión de la información pero no como fruto de una relación fiduciaria como la del corporate insiders, sino como resultado de una relación existente con la persona o entidad desde donde dicha información emana. Esta fórmula de apropiación indebida, ha pesar que ha sido utilizada, también lo es que ha sido frecuentemente criticada. 
ducta ilícita no pueden comprenderse la utilización de la información que los sujetos puedan realizar a partir de la función desempeńada y los cauces contemplados a estos efectos. La conducta será ilícita solo en los casos contemplados por el legislador.

El mandato legal se centra en varias conductas un tanto repetitivas que -en relación al sujeto antes descrito- serían exigidas o prohibidas, según el caso, estas son: 1. Guardar reserva de la información que se posea; 2. No utilizarla en beneficio propio o ajeno; 3. No adquirir o enajenar para sí o para terceros directamente o a través de otras personas los valores sobre los cuales posea información privilegiada; 4 . No valerse de la información privilegiada para obtener beneficios o evitar pérdidas, mediante cualquier tipo de operación con los valores a que ella se refiera o con instrumentos cuya rentabilidad esté determinada por estos valores. 5. Abstenerse de comunicar dicha información a terceros; y 6) No recomendar la adquisición o enajenación de los valores citados, velando para que esto tampoco ocurra a través de sus subordinados o terceros de su confian$\mathrm{za}^{112}$.

Ciertamente cuesta comprender la razón por la cual el legislador opta por enunciar un catálogo de conductas tan imbricadas, ocasionando una serie de problemas interpretativos ${ }^{113}$. En nuestra opinión, este mandato podría subsumirse en dos deberes concebidos desde una prohibición ${ }^{114}$ : El no uso de la información privilegiada (no utilizarla, a partir de una adquisición o enajenación, o de cualquier otra operación, para sí o para terceros, directamente o a través de otras personas ${ }^{115}$ ); y una obligación:

112 Llama la atención que nada se señale sobre las "declaraciones falsas" que en otras legislaciones de Derecho comparado si están consideradas como parte del mandato legal. Por ejemplo, respecto de EEUU, se puede citar el caso "SEC v/s Texas Gulp Sulphur Co.". En este caso, una empresa minera TGS, aun cuando acaba de descubrir un yacimiento, realiza por medio de sus ejecutivos, declaraciones falsas en un sentido opuesto, lo que hace bajar el precio de sus acciones para luego adquirirlas.

113 Por ejemplo, el Art. 81 de la LMV española señala como conductas prohibidas completamente diferenciadas entre si: "1. Preparar o realizar cualquier tipo de operación con los valores a los que la información se refiere o bien sobre otros de los que aquellos pueden constituir su subyacente. 2. Comunicar dicha información a terceros salvo en el ejercicio normal de su trabajo, profesión o cargo. 3. Recomendar a un tercero que adquiera o ceda valores o hacer que otro adquiera o ceda valores basándose en dicha información".

114 Doctrinalmente se también se han distinguido dos actos prohibidos: uso de la información privilegiada y la comunicación de la misma. Campos Graziani, Ricardo (2006). Insider Trading o Uso de información privilegiada, Santiago: Ed. Metropolitana; en igual sentido, Salah Abulseme (2002).

115 A modo de comparación, en EEUU, el deber y prohibición conductual se contiene en la 10b-5 de 1942, en la Ley de intercambio de Valores (SEA) dictada por la Securites Exchange Act (SEC). En particular, dicha disposición señala: "Será ilegal que cualquier persona, directa o indirectamente, por cualquier medio o instrumento del comercio entre los estados, o del correo o por cualquier medio de alguna bolsa nacional de valores: 1. Emplee cualquier medio, proyecto o artificio para defraudar. 2. Formule una afirmación falsa sobre un hecho relevante u omita citar un hecho material necesario en orden a hacer afirmaciones hechas, a 
el deber de abstención (no comunicar la información reservada, ni recomendar ninguna operación a partir de ella $\left.{ }^{116}\right)^{117}$. Pero también podría pensarse que se trata de una cuestión meramente semántica en tanto "no utilizar la información" también podría leerse en términos amplios, comprendiendo cualquier operación, como sería la adquisición, enajenación, divulgación (tipping), y/o recomendación de usar la información (tuyautage). También se puede diferenciar entre una prohibición interna, que implica la actuación del informado en la transacción (como adquirir o ceder los valores que posea); de prohibiciones de actuación externa que irradian su ámbito de actuación hacia el exterior (como revelar la información privilegiada o recomendar a un tercero una adquisición o cesión). Asimismo, se observan dos deberes concretos y complementarios a esta conducta: de reserva y de vigilancia en relación a los subordinados o terceros de confianza ${ }^{118}$.

La primera pregunta que surge es si las conductas exigidas en la disposición en comento presentan un carácter autónomo, en otras palabras, si cada una debe entenderse desligada de la anterior de manera tal que para determinar su ocurrencia debe analizarse la conducta en cuestión sobre la base de una acción concreta descrita por la ley. Así, por ejemplo, "No utilizar la información en beneficio propio o ajeno", podría constituir una conducta completamente distinta a "No adquirir o enajenar

la luz de las circunstancias en las cuales estas se efectúan, no equívoca, o 3. Se comprometa en cualquier acto, práctica o transacción comercial que opere o podría operar como un fraude o engaño sobre cualquier persona relacionada con la compra o venta de cualquier valor". La regla transcrita reconoce como fuente la sección 10b de la SEA de 1934 que dispone: "Es ilegal que cualquier persona, directa o indirectamente, por cualquier medio o instrumento del comercio entre los estados, a través del correo, o por cualquier medio de una bolsa nacional...b) Utilice o emplee, en relación a la compra o venta de cualquier título valor, registrado o no en bolsa, cualquier medio de manipulación o engańo o conspire en contra de las reglas que la Comisión prescriba como necesarias o apropiadas al interés público y para la protección de los inversionistas". El fundamento de esta prohibición reside en la injusticia que supone el uso de una determinada información a la que se accede sin divulgarla a la otra parte. Asimismo, existe normalmente un deber de fidelidad que se rompe vinculado a un deber fiduciario previo. Tal relación se da normalmente en la gestión societaria (corporate insiders), la obligación puede ampliarse a los outsiders (abogados, contadores y otros asesores) que están conectados a través de funciones precisas en el mercado de valores, y que si bien no tienen un deber fiduciario con los accionistas, se estima que tal restricción obedece a una mayor transparencia del mercado.

116 Esta conducta se conoce universalmente como Tipping (comunicar derechamente o a un tercero la información privilegiada) y Tuyautage (consejo que se da para adquirir o enajenar el título sin revelar la información privilegiada).

117 La Directiva Europea 2006/6/2003, diferencia a estos efectos, estos deberes. Así el art. 3o dispone: Los Estados miembros prohibirán a las personas sujetas a de las prohibiciones establecidas en el artículo 2: a) revelar información privilegiada a cualquier persona, a menos que se haga en el ejercicio normal de su trabajo, profesión o funciones; b) recomendar a otra persona que adquiera o ceda, o inducirle a ello, basándose en información privilegiada, instrumentos financieros a que se refiere dicha información.

118 Salah Abulseme (2002) 173-178. 
para sí o para terceros directamente o a través de otras personas los valores sobre los cuales posea información privilegiada", o de "Valerse de la información privilegiada para obtener beneficios o evitar pérdidas, mediante cualquier tipo de operación con los valores a que ella se refiera o con instrumentos cuya rentabilidad esté determinada por estos valores".

Lo complejo de estos casos, es que todas las conductas envuelven un contexto diferente, de manera tal que podría sostenerse que para configurarlas, debiera exigirse solo los elementos que se describen en cada una de ellas. En este camino, si se quiere sancionar el uso de información, este debiera realizarse "en beneficio propio o ajeno", y si lo imputado es la "adquisición de valores, habría de sostenerse que ella debe realizarse "para sí o para otro", sin necesidad de involucrar la idea del beneficio que antes señalamos, pues se entiende como una acción completamente diferente del uso de información privilegiada.

Esta ha sido la lógica seguida por la SVS al señalar que el Art. 165 contempla tres figuras infraccionales, las que consisten en: deber de reserva; prohibición de uso de la información privilegiada; y deber de abstención o prohibición de adquirir valores. El no uso de información privilegiada no excusa de cometer otra de las infracciones contenidas en el citado artículo 165 de la LMV, consistente ella en no cumplir con el deber de abstención de adquirir valores en los términos expuestos ${ }^{119}$. El argumento en cuestión trascendió en el caso LAN, luego que la SVS con fecha 10 de enero de 2007, mediante oficios reservados 003 y 004 formulara cargos a los seńores Piñera y Cueto por no observar el "deber de abstención" que pesa sobre quien tiene acceso a información privilegiada consistente en no adquirir para sí o para terceros, directa o indirectamente, los valores sobre los cuales posea dicha información. Con fecha 6 de julio de 2007 se confirmaron lo cargos y se aplicó una multa a cada uno de ellos ${ }^{120}$. La SVS formuló varias aseveraciones que de manera resumida podemos leer de la siguiente forma: a. Que el uso de información privilegiada es una figura independiente de la adquisición de valores; b. Debido a ello, alguien podría no utilizar información privilegiada, pero igual

119 Considerando No 18 de la Resolución No 306 y 307 de la SVS pronunciada en el caso LAN.

120 Lo relevante fue que con esa misma fecha, la SVS informó que había descartado el uso de información privilegiada ya que durante el proceso de descargos los implicados habían logrado acreditar que el conocimiento de dicha información financiera no fue la causa que motivó sus operaciones de compra. Asimismo, señaló que existe una prohibición legal de adquirir los valores sobre los cuales posea información privilegiada, de manera que existe un impedimento total y absoluto a estos efectos, sin necesidad de acreditar beneficio alguno. El fundamento reside en la necesidad que quienes tienen acceso a esta información no realicen acciones capaces de vulnerar la transparencia, simetría y competitividad que el mercado de valores requiere para funcionar adecuadamente y constituirse en el pilar de la actividad económica nacional. 
incurrir en el tipo infraccional de adquirir valores para sí o terceros; c. Dado la independencia de estas conductas, para esta última no se requiere acreditar intención del sujeto infractor ${ }^{121}$.

Discrepamos de esta solución, en tanto consideramos que se llega a ella solo a partir de una inadecuada interpretación normativa que no logra convencer ${ }^{122}$. En nuestra opinión, para resolver este asunto deben responderse dos interrogantes: ¿Qué implica el uso de información? y ¿qué envuelve la intencionalidad? El punto de inflexión es la necesaria interpretación que debe realizarse del vocablo "utilizar" que en nuestra opinión comprende diversos actos, se encuentren o no señalados en la disposición en comento ${ }^{123}$. El uso de información privilegiada es la conducta genérica de esta infracción que plantea diversas acciones u omisiones particulares, como la adquisición de valores, esta última resulta ser la forma o manera en que la información es utilizada. En otras palabras, el uso es un término amplio que denota una generalidad, en cambio, la adquisición y la enajenación resultan ser acciones concretas o particulares que se subsumen en la primera. Frente a ello, estimamos que la enunciación realizada por el legislador no es taxativa, ni categórica, de manera que no puede sostenerse que para configurar un determinado tipo infraccional deba reunirse un especial requisito, como sería la "intención de beneficios", y en un caso análogo desprenderse del mismo. Esto demuestra claramente que la norma es ineficiente pues provoca problemas de interpretación que no son menores, lo que nos lleva a afirmar que ella debe modificarse de acuerdo a un criterio unívoco.

121 Uno de los aspectos más criticados por la defensa de los involucrados consistió en el hecho que antes de esta sanción, la SVS no había nunca castigado tal conducta de manera independiente al uso de información privilegiada, cuestión que fue asumida por la SVS por medio de oficio reservado No218 de 8 de mayo de 2007.

122 En efecto, la SVS otorga una relevancia desmesurada al elemento de "intencionalidad" que acompaña la redacción normativa al uso de información privilegiada (al señalar "no podrá utilizarla en beneficio propio o ajeno"). De este modo, y considerando que la intencionalidad, según la SVS, no estaba en juego por cuanto este organismo ya había reconocido que el actuar de los reclamantes no había sido deliberado, descarta esta posible aplicación y subsume el actuar en una infracción aparentemente nueva y residual como es la "adquisición de valores" que, de acuerdo a su redacción normativa, no exige la aludida intencionalidad. En nuestra opinión, como veremos, esta conducta aun cuando fuera autónoma, siempre podría verse como una forma de uso de información privilegiada, y requiere la intencionalidad propia de este conjunto jurídico.

123 Así, por ejemplo, la legislación española concibe que la prohibición de emplear información privilegiada implica: adquirir, ceder, intentar adquirir, intentar ceder instrumentos financieros si se posee; recomendar a un tercero la adquisición, cesión o inducción a ello; revelar información privilegiada. 
La intención no puede entenderse como un elemento aislado, aun si no se señalase de todas maneras debiera tomarse en consideración para aplicar la responsabilidad infraccional respectiva. En este contexto, no podemos pensar en la intencionalidad como sinónimo de beneficios, sino como un elemento propio de la conducta descrita que subsume en sí mismo un elemento de culpabilidad (considerando que el sujeto sabía o debía saber que se trata de información privilegiada y que se encuentra prohibida su utilización en todas sus formas), de manera que no debe buscarse de manera adicional. La conducta se asienta sobre la base de un elemento volitivo de parte del sujeto infractor, toda vez que el legislador impide su utilización "en beneficio" propio o ajeno, o valerse de la información "para" obtener beneficios o evitar pérdidas; en tal sentido, todo uso de información privilegiada conlleva una idea de ganancia o asume la idea de beneficio, es parte de su esencia, en tanto el sujeto sabe que por medio de su uso está en una posición de ventaja comparativa con el resto de los inversores. Una cuestión distinta es que luego ello no suceda.

Otra interrogante que nace sobre el particular dice relación con la sanción que se deriva de los tipos infraccionales. Si lo que se protege es el correcto funcionamiento del mercado de valores a partir de la simetría de la información, es lógico que se castiguen todas las conductas por medio de una misma sanción. Derivado de ello, la mayor inquietud nace de la mano de la obligación de abstención, en tanto lo que corresponde preguntarse es si la sola comunicación de aquella a un tercero puede equipararse a la transacción realizada con la información, aun cuando aquella no sea utilizada por medio de ninguna operación. El legislador no distingue en este punto, por lo que debiéramos inclinarnos por una respuesta afirmativa, para comprender lo anterior, debemos necesariamente sostener que la "utilización" de la información debe concebirse en términos amplios, de manera que abarca diversas conductas como ocurre con la sola comunicación de la misma y, desde esta óptica, entender el acto consumado. En otras palabras, de acuerdo al legislador, la gravedad del asunto se encuentra en la utilización de la información privilegiada en cualquiera de sus formas, y no en los resultados de dicho actuar, de manera que basta la sola exposición al riesgo, o la creación de situación de peligro, para que la conducta sea castigada.

Finalmente, cabe advertir que esta prohibición, por sus propias características, tiene una dimensión temporal, toda vez que regirá este deber y conducta mientras la información tenga el carácter de privilegiada, esto es, no se haya dado a conocer al público. Frente a ello debemos recordar que el Art. 164 no pide que la información haya sido divulgada oficialmente al mercado, sino que admite cualquier tipo de difusión. 


\section{(3.4) ANÁLISIS DE LOS PRESUPUESTOS DE LA RESPONSABILIDAD EN EL USO DE LA INFORMACIÓN PRIVILEGIADA}

\section{a. Elemento volitivo del sujeto infractor: dolo y culpa}

Para configurar la responsabilidad, se requiere que el sujeto sea consciente de la antijuridicidad de su acción, lo que no implica que conozca concretamente cuál es el tipo jurídico que puede estar incumpliendo, ni el resultado de su actuar, lo importante es que sepa que la acción desarrollada es contraria al ordenamiento jurídico. En este trayecto debe integrarse el elemento subjetivo a partir del dolo y la culpa, a grandes rasgos esta última implica que el sujeto no fue capaz de imaginar todas las consecuencias de su acción, y que de haberse comportado diligentemente las podría haber conocido de manera que actuó con falta de previsibilidad de las consecuencias de su conducta.

Ahora bien, para que el resultado de la acción sea imputable a su autor se requiere la concurrencia de dos elementos esenciales: la inobservancia de un deber de cuidado y, como consecuencia un resultado que puede consistir en poner en peligro un bien jurídico o en dañarlo. El sujeto actúa diligentemente cuando cumple el deber objetivo de cuidado exigible a un hombre razonable o prudente, y por tanto prevé las consecuencias de su acción. Ello nos lleva a que no puedan ser consideradas imprudentes aquellas acciones cuyas consecuencias son imprevisibles o se desarrollan cumpliendo con el nivel objetivo de cuidado. Por el contrario, si su deber de diligencia es especialmente exigible, esto es, con arreglo a su deber subjetivo de cuidado, la gravedad del incumplimiento se agrava.

Adicionalmente, debe existir una relación de causalidad entre la culpa-dolo y la consecuencia provocada ${ }^{124}$. El problema que puede plantearse en este sentido, parte por aceptar la posibilidad que la conducta influya en los resultados, pero no sea del todo determinante. Consideramos que en este evento no puede descartarse la existencia de responsabilidad, habrá que determinar en cada caso la configuración de los elementos, pues en principio responderán como tales todas las personas que hubieren contribuido a la consumación del hecho delictivo entendido en un sentido amplio ${ }^{125}$.

124 Véase: Palma Jara, Eduardo. Informe en derecho, No1. Microjuris MJD151.

125 Debemos recordar que estos elementos serán valorados y apreciados desde diversas ópticas dependiendo del régimen sancionador a aplicar (penal, civil o administrativo). 


\section{b. Determinación del presupuesto obligacional subyacente}

¿Por qué el mandato legal se dirige a ciertos sujetos y no a otros? Con esta interrogante volvemos nuevamente sobre la cuestión de la naturaleza jurídica de la prohibición. Del art. 165 podemos colegir que este deber no se basa solo en un deber fiduciario existente entre el sujeto activo y el pasivo, pues la enunciación de posibilidades de conexión entre ambos no se subsume solo en la confianza del cargo o profesión desempeñada, sino que presenta un radio de acción más amplio, al entender que esta conexión podría nacer o provenir incluso del ejercicio de una simple actividad.

De este modo, si bien en algunos casos se justifica hablar de un deber de lealtad o fidelidad con el emisor, lo cierto es que no se trata de una explicación que transversalmente podamos conjeturar de manera general. Lo único que tienen en común tales situaciones, es una presunción legal amplia respecto de algunos sujetos que se puedan encontrar en las situaciones descritas en el Art. 165, entendiendo que ellos pueden llegar a poseer información privilegiada y como tal, el legislador les ordena comportarse de una determinada manera. Por tanto, la obligación legal no nace a partir de un vínculo único entre el sujeto y el emisor, afirmación que no hace sino confirmar lo que ya hemos expresado en las líneas anteriores, en el sentido que los fundamentos que recoge nuestra legislación para la configuración de esta materia son disímiles y equívocos, provocando confusión en la delimitación pertinente.

\section{c. Intención de beneficios: Posible graduación de la sanción}

Este es un tema que genera variadas problemáticas pues de acuerdo a lo preceptuado en el Art. 165, se trata de un requisito que no se exige en todos los casos, sino solo en dos: "quien posea información privilegiada deberá guardar reserva y no podrá utilizarla en beneficio propio o ajeno"; y "Asimismo, se les prohíbe valerse de la información privilegiada para obtener beneficios o evitar pérdidas". De manera tal que una interpretación estricta de la norma implicaría sostener que la intención de beneficios del sujeto infractor debe ser tenida en consideración para configurar la solo vulneración de estos tipos conductuales y no del resto.

Como adelantamos, nosotros nos inclinamos por una interpretación contraria, pues si lo reprimible es aprovecharse de la información, quien compra unos activos debe ser sancionado, aunque posteriormente no obtenga intención de beneficios, de no ser así, la comunicación de la información o la recomendación de adquisición de activos a terceros cuando no se demuestre la obtención de una contraprestación, no serían sancionables. Siguiendo esta lógica y los objetivos pretendidos por la prohibición del uso de información privilegiada, que inclusive formulan la 
potencialidad de influir en la cotización de los valores como parte de su configuración (Art. 164 LMV), consideramos que la infracción de uso de información privilegiada se debe entender consumada por el mero uso de la información, que podría implicar aún el traspaso de la misma a un tercero sin que luego se realice ninguna operación con ella.

En este sentido, lo lógico es pensar que la intención de beneficios se entiende incorporada al uso de dicha información, lo contrario limitaría injustificadamente las posibilidades de persecución y sanción ${ }^{126}$. Son los distintos campos sancionatorios los que podrán exigir este elemento; así, por ejemplo, la sanción administrativa o penal no requiere de la comprobación de beneficios para aplicar su normativa, mientras que una situación distinta ocurrirá desde la óptica civil o penal ${ }^{127}$. Asimismo, podría pensarse que la obtención de beneficios podría ser relevantes para la graduación de la pena (grave, muy graves, etc.), en relación al principio de proporcionalidad que debiera estar inserta en ella ${ }^{128}$.

Se trata de una materia que aún no logra pleno consenso en la doctrina jurisprudencial. Así se desprende del fallo pronunciado por la CS con fecha 27 de octubre de 2005, en la causa "Hurtado Vicuña, Juan y otros c/ Superintendencia de Valores y Seguros", ya antes singularizado, donde se analiza y confiere importancia justamente a los beneficios obtenidos lo que no consideramos apropiado. Si bien en un principio argumenta que no cualquier conocimiento de información es reprobable, pues muchas veces resulta inevitable el conocimiento previo por pequeños grupos de inversores de ciertas decisiones de compra y venta de acciones, luego la Corte agrega que lo censurable es el "hecho de servirse, de sacar provecho individual de la misma, sea obteniendo beneficios indebidos o evitando pérdidas económicas" que es lo que pretende proteger la LMV en su Art. $165^{129}$.

126 En este mismo sentido Gómez Iniesta (1997) 153.

127 Así, por ejemplo, el Art. 172 de la LMV, expresa en su inciso segundo y tercero: "Las personas que hayan actuado en contravención a lo establecido en este Título, deberán entregar a beneficio fiscal, cuando no hubiere otro perjudicado, toda utilidad o beneficio pecuniario que hubieren obtenido a través de transacciones de valores del emisor de que se trate. Aquel que infrinja lo dispuesto en el Art. 169, será responsable civilmente de los daños ocasionados al cliente respectivo o a los fondos en su caso, sin perjuicio de las sanciones penales y administrativas que correspondan".

128 En este mismo sentido, la graduación de la sanción a aplicar podría considerar el tamaño o la importancia de la entidad de que se trate (por ejemplo, en atención a su balance), toda vez que si el bien jurídico protegido es el orden público económico, en base a la posible repercusión que tendrán las cotizaciones de los valores en el mercado de valores, entonces, sería meridianamente lógico sostener que mientras mayor es el tamańo de la entidad, mayor será la repercusión que podrá generarse en la fluctuación del mercado en general.

129 En lo medular esta sentencia expresa: 230) Que, acorde a lo reflexionado, la conducta de los demandantes encuadra dentro de las hipótesis propuestas por el artículo 165 de la ley tantas veces citada, puesto que, en razón de ser Penta el grupo controlador del Banco de Chile, don Andrónico Luksic Craig sostuvo una reunión con ellos y les informó, a nombre 
En el caso LAN se discutió también sobre este punto. La defensa de Sebastián Piñera presentó una serie de pruebas tendientes a acreditar que en las operaciones realizadas no había mediado "intención de obtener ventajas económicas". Agregan que la legislación no impide ni prohíbe que los administradores de una sociedad inviertan en su empresa, este derecho se encuentra garantizado en el Art. $19 \mathrm{No} 23$ de la CP y regulado en el Art. 12 de la LMV y responde a los principios de libertad económica, libertad de contratación y autonomía de la voluntad que inspiran nuestro sistema jurídico y normativo ${ }^{130}$. La sentencia dictada sobre esta materia, caratulada "SVS c/ Cueto Plaza, Juan", pronunciada por la CA de Santiago con fecha 8 de marzo de 2010 -antes relatada- confirma la sanción aplicada por la SVS, y por tanto considera que "adquirir" es una conducta autónoma, mas no realiza un pronunciamiento particular sobre la intención de beneficios que debiera o no contemplarse en esta conducta. Esta sentencia fue acordada con un voto disidente ${ }^{131}$.

de Quiñenco S.A., que en los días inmediatamente posteriores, esta última entidad lanzaría una oferta pública de compra de acciones del Banco de Chile, por un valor de $\$ 50$ la acción, para incrementar así la posición que Quińenco S.A. tenía entre los accionistas de dicho Banco. En esta perspectiva, pese a estar en posesión de información, que revestía el carácter de privilegiada por lo explicado anteriormente, no cumplieron con la prohibición de utilizar en beneficio propio o de terceros relacionados tal información, sino que, por el contrario, recomendaron al Directorio la adquisición de las acciones ya referidas. Vale decir, se valieron y sirvieron indebidamente del conocimiento que poseían y la influencia que dicha información tendría sobre tales valores $(\ldots) ; 24^{\circ}$ ) Que, también es conducente resaltar que no están en lo cierto los demandantes cuando afirman que de su actuación no se habría derivado beneficio para ellos ni perjuicio para otras personas, ello por cuanto la operación de compra realizada por el Grupo Penta, al cual estos pertenecen, forzó al Grupo Luksic a negociar directamente con ellos la venta del paquete de control y, varios días después, Penta, Grupo Controlador del Banco de Chile, vendió al Grupo Luksic todas sus acciones en el Banco de Chile, recibiendo \$60 por acción y, como se recordará, días antes las habían adquirido en $\$ 50 ; 25^{\circ}$ ) Que tampoco tienen la razón los actores cuando sostienen que no habrían causado perjuicio alguno a terceros, puesto que su comportamiento implicó forzar el curso de los acontecimientos hacia su propia conveniencia, impidiendo que otros inversores pudieran participar, en igualdad de condiciones, de los beneficios de la operación ya descrita, resultando entonces agraviados estos últimos (...).

130 A mayor abundamiento, se argumenta que el Art. 165 de la LMV no contempla un deber de abstenerse de adquirir valores sobre los cuales se posee información privilegiada, prescindiendo del empleo y la utilización de esta información. Lo contrario vulneraría: i) El objeto y finalidad de la norma, que consiste en regular la utilización de información privilegiada; ii) La historia de su establecimiento; iii) Sería ajeno al sistema subjetivo de responsabilidad, ya que el deber de abstención sostenido en los cargos equivaldría a aplicar un criterio de responsabilidad objetiva, lo cual requeriría de texto expreso; iv) transgrediría el marco de potestad sancionatoria de la administración; y v) sería inconsistente con las sanciones aplicadas por la SVS. A juicio de la defensa, la SVS habría vulnerado los principios de tipicidad ya que la norma no contempla la conducta que se imputa, y de culpabilidad, por cuanto se intenta aplicar el principio de responsabilidad objetiva.

131 Se trata del voto del Abogado Integrante, quien estuvo por revocar la sentencia apelada y absolver al reclamante de los cargos impuestos por la SVS. 


\section{d. Existencia de daño}

¿Se considera el daño a estos efectos? Tomaremos un ejemplo para contextualizar el problema: supongamos que existen dos situaciones paralelas en que se ha vulnerado el mandato legal, en la primera el sujeto comunica una determinada información privilegiada a un tercero, mientras que en la segunda aquel efectúa operaciones de adquisición con ella. En el primer caso, el tercero no utiliza la información, mientras que en el segundo, a partir de la operación efectuada, se provocan variadas repercusiones para el mercado. ¿Podría castigarse de la misma forma a ambos sujetos? De acuerdo a lo visto, se debiera partir de la base que ambos han cometido una infracción, empero la graduación de la sanción pecuniaria que se aplique al efecto debiera tomar en consideración, a pesar del silencio legislativo, el daño provocado al mercado. Lo mismo debiera ocurrir visto el ejemplo desde la dimensión contraria, esto es, el tercero al que le traspasan la información la utiliza con fantásticos resultados calibrados en beneficios pecuniarios, mientras que el sujeto que utilizó la información no generó, en verdad, ninguna consecuencia en la operatividad del mercado, ni obtuvo beneficios personales.

En otras palabras, lo castigado debe ser la conducta, pero la sanción efectiva dependerá de las fuentes utilizadas (civiles, penales y administrativas), que aplicarán distintos criterios a estos efectos ${ }^{132}$. La gravedad de la conducta no puede medirse por el impacto que tengan los actos en el mercado, ante el silencio legislativo ambos deben ser considerados igualmente graves, este último tendrá relevancia para cuantificar el daño provocado y la consiguiente indemnización si hubiera lugar a ella. De esta forma, el daño no es un elemento esencial para la configuración la infracción, el legislador al tipificar esta conducta pone hincapié en la acción del sujeto y la situación de peligro que ella provoca. Este será fundamental para configurar ciertos tipos de responsabilidad ${ }^{133}$.

\section{e. Causales de exención de responsabilidad}

Para que se configure el uso ilícito de la información privilegiada deben reunirse los presupuestos legales anteriormente analizados. La comunicación de la información en el ejercicio de la profesión y cargo, a partir de los conductos legalmente establecidos a estos efectos, no implica uso de información privilegiada, pero tampoco lo será si no ha operado dolo o culpa en dicho actuar. De este modo, deben evaluarse en cada caso las

\footnotetext{
132 Véase Art. 172 LMV.

133 En relación a la responsabilidad civil, Véase: Salah Abusleme (2005) 202-204.
} 
posibles causas de antijuridicidad y de excusabilidad ${ }^{134}$ que pudieran estar presentes, las que comúnmente dicen relación con la falta de alguno de los presupuestos contemplados por el legislador, o bien la imposibilidad de parte del sujeto de haber tenido una conducta diferente. Entre estas deben considerarse aquellas situaciones en que no ha mediado el elemento volitivo por parte del sujeto, es decir, no ha obrado con culpa o dolo, como ocurre, por ejemplo, si un sujeto adquiere acciones emitidas por una sociedad anónima abierta por sucesión por causa de muerte o recibe crías o acciones liberadas de pago mientras posee información privilegiada; o le corresponda ejercer su derecho de suscripción preferente, al que no podría renunciar de acuerdo a la LSA. En todos estos casos, el sujeto posee información privilegiada, pero las operaciones o actos en que ha participado no se deben a ella, sino a otras circunstancias. En otras palabras, la información que posee el sujeto no importaría un antecedente para la ocurrencia de un determinado acto, operación o suceso, ni es causa de la determinación del precio de suscripción de las acciones o valores, de manera que no serían violados o afectados los bienes jurídicos protegidos por la normativa aplicable ${ }^{135}$.

En el caso LAN descrito anteriormente, se dio justamente una discusión sobre el particular. En la sentencia ya antes comentada, existe un pronunciamiento particular del abogado integrante que realizó el voto disidente al señalar que sin perjuicio de lo expuesto, él considera que la verdadera discusión de autos va más allá de los puntos referidos, en tanto lo que corresponde preguntarse es si el señor Cueto Plaza podía o no adquirir las acciones. Al respecto recuerda que siendo Director de LAN y aprobando el estado financiero de la compañía, este procedió a comprar 250.000 acciones de LAN ese mismo día (antes de ser divulgada la información) por parte de otra sociedad de la que era principal accionista. Para responder, pone en jaque con este hecho, el derecho que gozan los

134 En algunas normativas de Derecho comparado se prevén diversas circunstancias que implican la no utilización ilegal de la información privilegiada, por ejemplo: aquellas que se realicen en cumplimiento de una obligación de adquirir o ceder valores negociables o instrumentos financieros, siempre que dicha obligación esté contemplada en un acuerdo celebrado con anterioridad; operaciones efectuadas para ejecutar la política monetaria de tipo de cambio o de gestión de la deuda pública; operaciones sobre acciones propias en el marco de programas de recompra efectuados por los emisores, cuando existan medidas preventivas en la propia empresa para evitar la utilización de información privilegiada que la propia empresa posea; operaciones dirigidas a la estabilización de un valor negociable o instrumento financiero, siempre que en estos dos últimos casos se efectúen de acuerdo con las condiciones que se determinen reglamentariamente.

135 E. Palma Jara se acerca a este entendimiento, pero no en base al mismo presupuesto. En efecto, para el autor ello se funda en la exigencia de voluntad e intencionalidad del sujeto en orden a aprovecharse de la misma y adquirir valores emitidos por la compañía, en una clara ventaja ilegítima respecto de los demás actores del mercado, y como hemos visto, tal situación no es necesaria para la configuración de este ilícito. Véase. PaLma Jara, MJD151. 
directores para ser informados plena y documentadamente, y en cualquier tiempo por el gerente o el que haga sus veces de todo lo relacionado con la marcha de la empresa (Art. 39 LSA). De esta manera, si el director dispone permanentemente de la información cualitativa y cuantitativa de la empresa que no está a disposición del público significa que el Director pueda quedar impedido de administrar su patrimonio, pues nunca podría comprar acciones de dicha empresa. Si fuera así, agrega, se daría el absurdo que ningún accionista podría entrar a formar parte de un Directorio pues, en tal caso, pasaría a tener una incapacidad especial. Concluye señalando que dicha alternativa colisiona gravemente con el derecho de dominio y la libertad económica que consagra la Constitución Política ${ }^{136}$.

No concordamos con lo aquí planteado. El Abogado Integrante básicamente señala que como un Director siempre puede acceder o poseer información privilegiada en razón de su cargo, entonces siempre podría realizar operaciones con dicha información en el entendido que forma parte de un derecho esencial. En tal sentido, afirma que no podría restringirse tal posibilidad por estar en juego el derecho de dominio y la libertad económica consagrados por la Constitución Política. Si bien concordamos con la afirmación que la norma en comento debe interpretarse de manera restrictiva, no es posible afirmar que el castigo puede ser aplicado "únicamente" cuando no debamos acudir a interpretaciones, ello es precisamente lo que debe realizarse, es decir, determinar, a través de un análisis exegético de la ley si las personas involucradas se subsumen en dicho actuar $^{137}$. Lo que procedía era demostrar la concurrencia de una causal

136 Al respecto expresa: “17. Que, en efecto, en el área constitucional dos principios rectores se deben tener presente: a) el principio de reserva legal; y b) el mandato expreso contenido en el numeral 26 de la Carta Fundamental que consagra la seguridad de que los preceptos legales que por mandato de la Constitución regulen o complementen las garantías que esta establece o que las limiten en los casos en que ella lo autoriza, no podrán afectar los derechos en su esencia, ni imponer condiciones, tributos o requisitos que impidan su libre ejercicio. 18.Que, en consecuencia, tratándose de normas legales que no solo regulan sino que limitan garantías constitucionales, su interpretación debe efectuarse en forma restrictiva, ponderada y serena; luego, se debe aplicar castigo únicamente cuando la conducta esté expresamente descrita por la ley sin tener que recurrir a interpretaciones; y, finalmente, la sanción debe ser la que la ley señala en forma expresa para tal conducta y nunca una pena residual. 19.- Que, en síntesis, en el presente caso, estando descartada la utilización indebida de información privilegiada, la adquisición por parte de un Director de acciones su propia compañía, carece de naturaleza infraccional por lo cual no resultaba jurídicamente procedente aplicar sanción alguna al Director Cueto Plaza".

137 Es preciso considerar que en el caso narrado, el Director sancionado tuvo acceso a una información que tenía el carácter de privilegiada (en el entendido que reunía los requisitos contemplados en el Art. 165, en especial, su relevancia y falta de publicidad) e incumplió el deber de inactividad contemplado por la ley, al haber procedido a adquirir acciones de la compañía que generó la información sin ser esta comunicada al público aún. El asunto es que el cargo desempeñado le imprime no solo derechos, sino también deberes, y entre estos se encuentran los de no utilizar la información privilegiada de ninguna de las formas establecidas en la LMV. Señalar que con ello se restringen sus derechos de propiedad y libertad 
de exoneración, es decir, que la adquisición de los valores por parte del director no era consecuencia de la información privilegiada, sino de otras situaciones que no se conectan a aquella, lo que en definitiva no logró acreditarse.

A mayor abundamiento, debemos considerar que no se trata de una afectación desprovista de motivación, la limitación impuesta en al LMV opera sobre un límite de esta autonomía de la voluntad sobre la base de un bien superior, como es, el resguardo del Orden Público Económico.

\section{f. Responsabilidad por hecho ajeno}

La disposición en comento, en su inciso segundo, reconoce la figura de la responsabilidad por hecho ajeno al señalar: "Igualmente, se abstendrán de comunicar dicha información a terceros o de recomendar la adquisición o enajenación de los valores citados, velando para que esto tampoco ocurra a través de subordinados o terceros de su confianza”. Esta infracción se basa en una posición de garante que el legislador confía en un tercero y que lo hace responsable solidaria o subsidiariamente de las infracciones cometidas por otra persona, y que puede ser tanto una persona física como jurídica. De lo anterior surgen varias interrogantes: ¿Debe el garante responder en todo caso o solo cuando ha actuado con dolo o culpa?, ¿qué implicancias tienen los vocablos "subordinados" y "terceros de su confianza"? y ¿debe responder el garante solidaria o subsidiariamente con el tercero? La disposición no se basta a sí misma para responder estas y otras inquietudes, por lo que tenemos que interpretar el enunciado de la manera más armónica posible.

Se desprende que el legislador, por medio del verbo "velar" impone un deber al cuidado al sujeto en cuestión, de manera tal que responde por el tercero solo si este no ha empleado tal deber, lo que implica que deben existir culpa o dolo en tal actuar. En tal sentido, la responsabilidad del garante nace porque de alguna forma ha participado en los hechos, pues al no actuar de manera diligente, o no prever las consecuencias de su acción, ha favorecido la comisión de la infracción de otra persona.

$\mathrm{Al}$ mismo tiempo, el ámbito de aplicación subjetivo es restrictivo, en tanto tal deber y consiguiente responsabilidad solo emergerán por actos de "subordinados o terceros de su confianza", de manera que responde solo ante tales supuestos. La noción de subordinados, necesariamente debemos entenderla en un contexto laboral, empero no todo inferior jerár-

económica es un fundamento feble, en tanto lo que se prohíbe es que estos sujetos no puedan utilizar la información "mientras tenga el carácter de privilegiada", tomando en consideración que en principio es un período breve, para no provocar distorsiones en la operatividad del mercado de valores y discriminaciones injustificadas. Una vez que la información deja de tener tal carácter, el sujeto puede hacer las operaciones que estime pertinentes. 
quico quedará incorporado en esta expresión, en tanto la norma se sienta sobre un deber que solo puede existir en una posición jerárquica directa, que permita al garante cumplir su misión de cuidado. La segunda expresión es más amplia que la anterior, y por tanto, su interpretación resulta más imbricada, pues existen varias categorías que podrían subsumirse en aquella. Así, perfectamente podrían ser incluidos los familiares y amigos más cercanos, siempre que tuvieren la condición de "cercanos", y debe ser acreditado a menos que se trate de alguna de las personas señaladas en el Art. 166 de la LMV, lo que vendrá a conmover y complejizar la concreta delimitación de este escenario.

Como advertimos más atrás, la conducta no pide que el tercero use la información, lo que se castiga es el deber de cuidado que debe tener el sujeto potencialmente responsable al crear o no resguardar la ocurrencia de una situación de peligro, por ello se le exige un deber de diligencia. Finalmente, la norma no aclara el tipo de responsabilidad que recaerá sobre el garante, de manera que habrá que entender que se trata de una responsabilidad subsidiaria ${ }^{138}$.

138 Sobre este tema, podría servirnos de referencia la sentencia dictada por la CA de Antofagasta, con fecha 10 de enero de 2010, en causa "Collado Cerda, Jorge c/Codelco División Codelco Norte", que pronunciándose sobre un recurso de apelación de un despido injustificado en que se argumentó justamente el "uso de información privilegiada" como causal de despido. En concreto señaló: "Tercero: Que, las causales de caducidad del contrato dependen de la conducta del trabajador y exigen que ellas sean debidamente probadas. La causal invocada por la demandada en su carta de término de contrato de trabajo de fecha 10 de septiembre de 2008, agregada a fojas 11 , es la prevista en el artículo $160 \mathrm{~N}^{\circ} 1$, letra a) del Código del Trabajo, esto es, la falta de probidad en el desempeño de sus funciones. Esta causal no ha sido definida por el legislador, ella debe ser entendida en su sentido natural y obvio, como sinónimo de falta de integridad y honradez, por lo que los hechos que la constituyen deben ser debidamente probados, debiendo revestir cierta gravedad y significación. El legislador califica a la conducta de indebida, es a la única causal que le ha impuesto una exigencia probatoria, de manera tal que ella produzca plena convicción en el sentenciador al momento de configurarla. Cuarto: Que, esta Corte coincide con el juez sentenciador de primer grado, en tanto en los considerandos duodécimo, decimotercero y decimocuarto establece que no existe prueba suficiente que permita configurar la causal invocada por el empleador para el despido del trabajador, demandante de autos, atendido que se aprecia la ausencia de prueba respecto de la función que desempeńaba en el cargo para el que fue contratado, más allá de indicar que se contrató como Geólogo Experto, sobre la forma de acceso que el trabajador tuvo a la información privilegiada que se habría permitido traspasar a su esposa empresaria, si esta información era o no parte de la función ordinaria que el trabajador tenía en el desempeño de su trabajo, asimismo la vinculación entre esta función e información reservada y los negocios de la cónyuge, como el conflicto de intereses entre la empresa Codelco y la cónyuge del demandado". 


\section{4) Problemáticas Visualizadas a PARTIR de LA NORMATIVA EX- PUESTA Y ANALIZADA}

Para nadie es un misterio que la información privilegiada es un bien que sufre, en general, definiciones confusas, derechos mal especificados, altos costos de monitoreo y poco conocimiento de su verdadera naturaleza ${ }^{139}$. La regulación que el legislador chileno ha generado sobre el particular no ha sido una excepción, por el contrario, los fallos que se han pronunciado sobre los elementos que configuran el uso de información privilegiada, así como de las conductas sancionadas, han venido a confirmar lo que ya parte de la doctrina venía pregonando: tanto el concepto de uso de información privilegiada, como las conductas exigidas, son equívocas y se requiere de un trabajo de disección e interpretación no menor que tienda a develar el verdadero significado de las mismas.

En el presente trabajo hemos constatado e intentado responder gran parte de estas confusiones, al mismo tiempo que planteamos nuevos dilemas e interrogantes con el objeto de que ellos sean considerados tanto por el intérprete, como por el legislador. En lo medular, y a modo de conclusión, destacamos las siguientes ideas:

4.1. La regulación del uso de información privilegiada es necesaria para mantener los equilibrios y confianzas del mercado de valores. Dicha regulación deber ser adecuada y eficiente para el logro de estos objetivos, en tanto si no se resguarda de esta manera se corre el riesgo de vaciar de contenido el fundamento de esta regulación.

4.2. Existe disparidad y falta de claridad sobre los elementos configuradotes de la noción de uso de información privilegiada. En tal sentido, se evidencian tres tipos distintos de posibles informaciones privilegiadas, cada uno de ellos con un especial diseño y construcción. No se comprenden bien las razones por las cuales el legislador opta por formular estas tipologías, disímiles entre sí, en vez de entregar un solo concepto de aplicación general y amplio que tienda a resguardar los principios y objetivos que consagra la normativa ${ }^{140}$.

No se comprende por qué la norma es rigurosa en la delimitación del ámbito de aplicación objetivo de la información privilegiada concebida en términos generales, si luego, para los casos especiales (información reservada y la relativa a inversionistas institucionales) no se emplean los

139 Gietze (1999) 819.

140 En otras legislaciones, como la espańola ya no se menciona a la información reservada a estos efectos. La distinción y conjunción se realiza entre la información privilegiada y la relevante. En concepto de Entrena Ruiz, los conceptos de información privilegiada y relevante serían coincidentes, la única diferencia se encontraría en que si ella no llega a difundirse se entiende como privilegiada, mientras que si es publicada, será relevante. Entrena Ruiz (2006) 76. 
mismos criterios. Ciertamente se trata de una materia en que extrańamos una relectura y mayor precisión.

4.3. Como vimos en su oportunidad, son variadas las interrogantes que emergen del análisis del Art. 165 LMV y, más aún, de la exacta delimitación del ámbito de aplicación subjetiva y las conductas asociadas al mandato legal que allí reside. Frente a ello, tenemos que considerar que esta amplia extensión del tipo infraccional y los sujetos que pueden verse implicados en dichas conductas, conlleva el riesgo de suprainclusión de conductas.

La mayor parte de estas inquietudes descansan en problemas concretos, que deben revisarse a partir de variables que no siempre se encuentran visibles, ni son consideradas, como son: la determinación de la fuente obligacional, la correcta delimitación del centro de imputación de las mismas, el objeto protegido en esta regulación, y el análisis de los derechos involucrados, en especial de los que nacen de la autonomía de la voluntad, y los que se fundan en causales de orden público.

Asimismo, volvemos a poner hincapié en la necesidad de advertir los elementos de responsabilidad que impregnan la conducta exigida, de manera de diferenciar claramente, por ejemplo, que la intención que ha de estar presente en el sujeto infractor debe tener una relación directa con el conocimiento que se tenga sobre el carácter de la información, y no con el ánimo de lucro especialmente.

4.4. Finalmente, somos enfáticos en afirmar que el mandato legal debiera ser más claro en relación a las conductas infraccionales y sujetos que pueden sancionarse que, tal como vimos, carecen en la actualidad de una interpretación unívoca. En tal sentido, abogamos por la modificación de esta norma en los términos que ya nos hemos referido, acentuando la necesidad de contar con la absoluta claridad sobre la naturaleza jurídica y fundamentos que subyacen a esta institución, como mecanismo de construcción y delimitación efectivo.

Hacemos presente que no se puede obviar que esta articulación afecta el terreno fáctico, en tanto se trata de una noción que reviste una enorme relevancia en la operatoria del mercado de valores y el flujo de posibles inversiones e inversionistas, por ello resulta relevante considerar que las consecuencias de contar con un sistema confuso sobre esta materia pueden alertar y/o desalentar a posibles inversionistas que operan en el mercado, en base a las inconsistencias y peligros que conlleva la toma de decisiones.

\section{BIBLIOGRAFÍA}

- Alcalde Rodríguez, Enrique (2000). "Uso de información privilegiada: Algunas consideraciones sobre el sentido y alcance de la prohibición en relación con su sujeto, objeto y sanción”, Revista Chilena de Derecho, ańo 27, No1. 
- Alcalde Silva, Jaime (2010). "La extensión temporal del deber de secreto de los administradores sociales", Revista de Derecho Mercantil No 275, pp. 7-73.

- Arroyo Zapatero, Luis (1994). El abuso de información privilegiada en el Derecho penal español, Estudios de Derecho penal económico, Cuenca: Ediciones de la Universidad Castilla-La Mancha.

- Bustos Ramírez, Juan (1991). "Perspectivas actuales del Derecho Penal Económico", Revista Gaceta Jurídica, No 132.

- Campos Graziani, R. (2006). Insider Trading o Uso de información privilegiada, Santiago: Metropolitana.

- Castells, Manuel (2008). La era de la información, Vol I, Madrid: Alianza Editorial.

- Entrena Ruiz, Daniel (2006). El empleo de información privilegiada en el mercado de valores: Un estudio de su régimen administrativo sancionador, Navarra: Ed. Thomson-Civitas.

- García Santos, Ma Nieves (2005). "Ética, equidad y normas de conducta en los mercados de valores: la regulación del abuso de mercado", Revista Ética y Economía No 823, pp. 163-183.

- Gisze, Craig R (1999). "El análisis económico de la información privilegiada en el mercado de capitales y valores: ¿justicia ineficiente?", Revista Chilena de Derecho, año 26 No4.

- Gómez Iniesta, Diego (1997). La utilización abusiva de información privilegiada en el mercado de valores, Madrid: Mc. Graw Hill.

- Guzmán Anrique, Francisco (2009). Información privilegiada en el mercado de valores chileno, Santiago: LegalPublishing.

- Hernández Basualto, Héctor (2005). "Perspectivas del Derecho penal económico en Chile", en Persona y Sociedad, Vol. XIX, No1.

- Hernández Sainz, E. (1998). "La prohibición de los abusos de información privilegiada en el Derecho del Mercado de Valores francés", Revista de Derecho Bancario y Bursátil, No 71.

- Informe Comisión de Hacienda, Historia de la ley 20.382 (2009). Disponible en: www.bcn.cl

- Lazen, V. / Eguiluz, C. (2006). "Conflictos de interés en servicios financieros: taxonomía y mecanismos de control regulatorio", Documentos de Trabajo 6, Serie de Documentos de Trabajo, SVS, Disponible en: www.svs.cl

- López Barja de Quiroga, Jacobo (1998). "El abuso de información privilegiada”, en Bacigalupo, E. (Ed.): Curso de Derecho Penal Económico, Madrid: Marcial Pons.

- López Lozano, M.A (2002). "La información privilegiada en los mercados de valores. Aportaciones de la jurisprudencia de los Estados Unidos", La Ley, año 1997, № 4.

- Novoa Galán, Raúl / Novoa Muñoz, Gabriela (1997). Derecho del mercado de capitales, $2^{\text {a }}$ edición, Santiago: Editorial Jurídica de Chile. 
- Palma Jara, Eduardo. Informe en Derecho No1. Microjuris MJD151.

- Prado Puga, Arturo (2003). "Acerca del concepto de información privilegiada en el mercado de valores chileno: su alcance, contenido y límites", Revista Chilena de Derecho, año 30, No 2.

- Piña Rochefort, Juan Ignacio (2010). "Algunos problemas del delito de uso de información privilegiada", en González Iturria, Marco (Ed.): Regulaciones en el mercado de valores, Cuadernos de Extensión Jurídica No 19, Santiago: Universidad de los Andes.

- Puelma Accorsi, A. (1998). Sociedades, 2a edición, Santiago: Ed. Jurídica de Chile.

- Ramírez, V. / YÁÑez, G. "Información de los estados financieros y períodos de Blackout: evidencia para Chile", Documento de Trabajo No10, Serie Documentos de Trabajo, Superintendencia de Valores y Seguros, Chile. Disponible en: www.svs.cl;

- Ried Undurraga, José Miguel (2004). "Fundamentos de la prohibición del uso de la información privilegiada en Chile: una visión crítica", Revista Chilena de Derecho, año 31, No 2.

- Salah Abulseme, María Agnes, (2005). Responsabilidad por uso de información privilegiada en el mercado de valores, Santiago: LexisNexis.

- Sánchez-Calero Guilarte, Fernando (1987). "En torno al concepto de información privilegiada (insiders Trading y operaciones de iniciado)", Revista de Derecho Bancario y Bursátil.

- Sandoval López, Ricardo (2005). Derecho comercial. Sociedades de personal y capital, 6a edición, Tomo I, Santiago: Ed. Jurídica de Chile.

- Vasquez Palma, Ma. Fernanda, (2010). "Caso Lan y uso de información privilegiada: un análisis de la correcta delimitación de las infracciones legales", Ius et Praxis, No 2 (en prensa).

- Varela Morgan, Raúl. Informe en Derecho No3 "Adquisición de acciones sociales: Uso de información privilegiada”. MJD153.

- Zarhi Villagra, Oscar (2010). "La teoría de los mercados eficientes como garantía de una correcta fiscalización del mercado de valores", en Gónzalez Iturria, Marco (Ed.): Regulaciones en el mercado de valores, Cuadernos de Extensión Jurídica No 19, Santiago: Universidad de los Andes.

- Zunzunegui, F. (2005). Derecho del mercado financiero, $3^{a}$ edición, Madrid-Barcelona: Marcial Pons. 